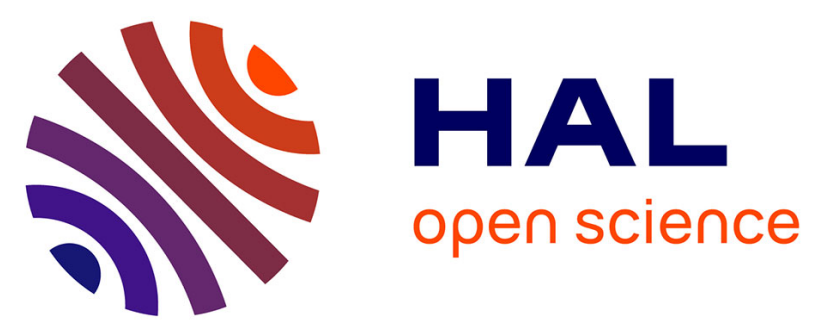

\title{
Cyclipostins and Cyclophostin Analogues as Multitarget Inhibitors That Impair Growth of Mycobacterium abscessus
}

Abdeldjalil Madani, Jeremy Ridenour, Benjamin Martin, Rishi Paudel, Anosha Abdul Basir, Vincent Le Moigne, Jean-Louis Herrmann, Stéphane Audebert, Luc Camoin, Laurent Kremer, et al.

\section{To cite this version:}

Abdeldjalil Madani, Jeremy Ridenour, Benjamin Martin, Rishi Paudel, Anosha Abdul Basir, et al.. Cyclipostins and Cyclophostin Analogues as Multitarget Inhibitors That Impair Growth of Mycobacterium abscessus. ACS Infectious Diseases, 2019, 10.1021/acsinfecdis.9b00172 . hal-02276160

\section{HAL Id: hal-02276160 \\ https://hal-amu.archives-ouvertes.fr/hal-02276160}

Submitted on 30 Jan 2020

HAL is a multi-disciplinary open access archive for the deposit and dissemination of scientific research documents, whether they are published or not. The documents may come from teaching and research institutions in France or abroad, or from public or private research centers.
L'archive ouverte pluridisciplinaire HAL, est destinée au dépôt et à la diffusion de documents scientifiques de niveau recherche, publiés ou non, émanant des établissements d'enseignement et de recherche français ou étrangers, des laboratoires publics ou privés. 
Cyclipostins and Cyclophostin analogs are multi-target inhibitors that impair growth of Mycobacterium abscessus

Abdeldjalil Madani $^{1 \S}$, Jeremy N. Ridenour ${ }^{2 \S}$, Benjamin P. Martin ${ }^{2}$, Rishi R. Paudel ${ }^{2}$, Anosha Abdul Basir $^{2}$, Vincent Le Moigne ${ }^{3}$, Jean-Louis Herrmann ${ }^{3,4}$, Stéphane Audebert ${ }^{5}$, Luc Camoin ${ }^{5}$, Laurent Kremer $^{6,7}$, Christopher D. Spilling ${ }^{2 *}$, Stéphane Canaan ${ }^{1}$ and Jean-François Cavalier ${ }^{1 *}$

${ }^{1}$ Aix-Marseille Univ, CNRS, LISM, Institut de Microbiologie de la Méditerranée, Marseille, France.

${ }^{2}$ Department of Chemistry and Biochemistry, University of Missouri-St. Louis, One University Boulevard, St. Louis, Missouri 63121, USA.

${ }^{3}$ APHP, GHU PIFO, Hôpital Raymond-Poincaré - Hôpital Ambroise-Paré, Boulogne-Billancourt, France.

${ }^{4}$ 2I, UVSQ, INSERM UMR1173, Université Paris-Saclay, Versailles, France.

${ }^{5}$ Aix Marseille Univ, CNRS, INSERM, Institut Paoli-Calmettes, CRCM, Marseille Protéomique, Marseille, France.

${ }^{6}$ Institut de Recherche en Infectiologie de Montpellier (IRIM), CNRS, UMR 9004, Université de Montpellier, 34293 Montpellier, France.

${ }^{7}$ IRIM, INSERM, 34293 Montpellier, France.

$\S^{\S}$ Both authors contributed equally and should be considered as first co-authors.

\section{* To whom correspondence should be addressed}

E-mail address: SpillingC@ msx.umsl.edu (C.D. Spilling); Phone: 314-516-5899

E-mail address: jfcavalier@imm.cnrs.fr (J.-F. Cavalier); Phone: +33 491164093 
Twelve new Cyclophostin and Cyclipostins analogs $(\mathbf{C y C} \mathbf{C 1 9 - 3 0})$ were synthesized, thus extending our series to 38 CyCs. Their antibacterial activities were evaluated against four pathogenic mycobacteria (Mycobacterium abscessus, Mycobacterium marinum, Mycobacterium bovis BCG and Mycobacterium tuberculosis) and two Gram negative bacteria. The CyCs displayed very low toxicity towards host cells and were only active against mycobacteria. Importantly, several CyCs were active against extracellular $M$. abscessus $\left(\mathrm{CyC}_{17} / \mathrm{CyC}_{\mathbf{1 8} \beta} / \mathrm{CyC}_{25} / \mathbf{C y C}_{26}\right)$ or intramacrophage residing mycobacteria $\left(\mathbf{C y C}_{\mathbf{7}(\boldsymbol{\alpha}, \boldsymbol{\beta})} / \mathbf{C y C}_{\mathbf{8}(\boldsymbol{\alpha}, \boldsymbol{\beta}))}\right)$ with minimal inhibitory concentrations (MIC $\left.\mathbf{C}_{50}\right)$ values comparable to or better than those of amikacin or imipenem, respectively. An activity-based protein profiling combined with mass spectrometry allowed identification of the potential target enzymes of $\mathrm{CyC}_{17} / \mathbf{C y C}_{26}$, mostly being involved in lipid metabolism and/or in cell wall biosynthesis. Overall, these results strengthen the selective activity of the $\mathbf{C y C s}$ against mycobacteria, including the most drug-resistant $M$. abscessus, through the cumulative inhibition of a large number of Ser- and Cysenzymes participating in key physiological processes.

Keywords: Total synthesis; drug susceptibility; activity based-protein profiling; proteomics analysis. 
Produced by Streptomyces species, ${ }^{1}$ natural Cyclophostin $\left(\mathbf{C y C}_{\mathbf{1}}-\mathbf{F i g u r e} \mathbf{1}\right)$ is characterized by a unique seven-membered cyclic phosphate triester fused to a butyrolactone ring. This bicyclic core also contains a unique enol phosphate and chiral centers at both phosphorus and C-3a carbon atom. The structurally related natural Cyclipostins (e.g., Cyclipostin P CyC18 $\beta$ - Figure 1), which varied in the nature of the lipophilic chain attached to the phosphate, were described as bacterial growth inhibitors of various mycobacteria. ${ }^{2}$ Together, compelling evidence suggests the great potential for cyclic enolphosphate and phosphonate analogs of Cyclophostin (and the Cyclipostins) as anti-mycobacterial agents.

To explore this hypothesis, we have reported the synthesis of Cyclipostins and Cyclophostin analogs (namely the CyCs - Figure 1) ${ }^{3-6}$ We first demonstrated that this first series of $26 \mathbf{C y C s}$ (Figure 1) was able to efficiently inhibit the growth of Mycobacterium tuberculosis $\mathrm{H} 37 \mathrm{Rv}$, in vitro as well as in infected macrophages, with very low toxicity towards the host cells. ${ }^{7}$ These studies also strongly support the assumption that $\mathbf{C y C}$ compounds are multi-target inhibitors impairing various mycobacterial Ser- or Cys-containing enzymes involved in important physiological processes via the formation of a covalent bond between the enol-phosphorous atom and the catalytic residue..$^{4-5,7-9}$ The efficiency/selectivity of these CyCs was investigated further towards three slow-growing species (i.e., M. marinum, M. bovis BCG, and M. tuberculosis) and various mycobacterial clinical isolates and bacteria responsible for nosocomial infections, including Gram-negative and Gram-positive bacteria as well as rapidly-growing mycobacteria (RGM) belonging to the Mycobacterium chelonaeabscessus clade. ${ }^{10}$ Remarkably, the inhibitory activity of these CyCs was exclusively restricted to mycobacteria. ${ }^{10}$ Notably, the most potent inhibitor $\left(\mathbf{C y} \mathbf{C}_{\mathbf{1 7}}\right)$ exhibited minimal inhibitory concentrations (MIC) values comparable to those of most classical antibiotics used to treat $M$. tuberculosis and M. abscessus infections. ${ }^{7,}{ }^{10}$ Collectively, these results emphasized the attractiveness of this new family of compounds as valid drug candidates to be exploited in future therapeutic developments against mycobacterial-associated infections, especially against $M$. abscessus the most drug-resistant mycobacterial species. ${ }^{10}$ 


$$
\begin{aligned}
& \text { Cyclophostin: } X=\mathrm{O} ; \\
& \qquad \begin{aligned}
\mathrm{R}^{2}=\mathrm{H} ; \mathrm{R}^{1}=\mathrm{R}^{3}=\mathrm{CH}_{3} \\
\text { Cyclipostins: } \mathrm{X}=\mathrm{O} ; \mathrm{R}^{2}=\mathrm{H} \\
\mathrm{R}^{1}=\mathrm{C}_{15} \text { to } \mathrm{C}_{16} \\
\mathrm{R}^{3}=\mathrm{CH}_{3}, \mathrm{C}_{2} \mathrm{H}_{5}, n-\mathrm{C}_{3} \mathrm{H}_{7}
\end{aligned}
\end{aligned}
$$

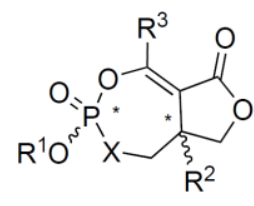

CyC analogs

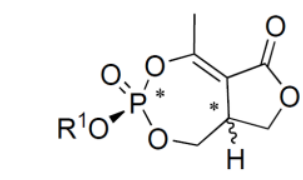

$\mathrm{CyC}_{1}\left(R_{\mathrm{c}}, R_{\mathrm{p}}\right)\left(\mathrm{R}^{1}=\mathrm{Me}\right)$

$\mathrm{CyC}_{18 \beta} \operatorname{cis}-\left(R_{\mathrm{c}}, R_{\mathrm{p}}\right)\left(\mathrm{R}^{1}=\mathrm{C}_{16} \mathrm{H}_{33}\right)$

CyC ${ }_{18 \alpha}$ trans $-\left(S_{\mathrm{c}}, R_{\mathrm{p}}\right)\left(\mathrm{R}^{1}=\mathrm{C}_{16} \mathrm{H}_{33}\right)$

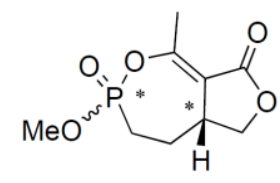

$\mathrm{CyC}_{2 \beta} \operatorname{cis}-\left(S_{\mathrm{c}}, R_{\mathrm{p}}\right)$

$\mathrm{CyC}_{2 \alpha}$ trans- $\left(S_{\mathrm{c}}, S_{\mathrm{p}}\right)$

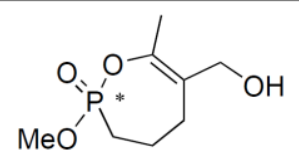

racemic $\mathrm{CyC}_{3}$

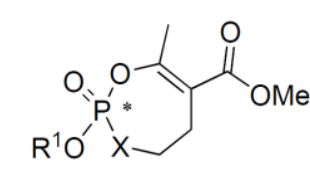

$$
\left\{\begin{array}{l}
\mathrm{CyC}_{14}\left(\mathrm{R}^{1}=n-\mathrm{C}_{16} \mathrm{H}_{33} ; \mathrm{X}=\mathrm{CF}_{2}\right) \\
\mathrm{CyC}_{15}\left(\mathrm{R}^{1}=\mathrm{C}_{2} \mathrm{H}_{5} ; \mathrm{X}=\mathrm{CF}_{2}\right) \\
\mathrm{CyC}_{16}\left(\mathrm{R}^{1}=\mathrm{Me} ; \mathrm{X}=\mathrm{O}\right) \\
\mathrm{CyC}_{17}\left(\mathrm{R}^{1}=n-\mathrm{C}_{16} \mathrm{H}_{33} ; \mathrm{X}=\mathrm{O}\right)
\end{array}\right.
$$

Figure 1. Chemical structure of natural Cyclipostins and Cyclophostin, and related CyC analogs. Natural Cyclophostin $\left(\mathbf{C y C} \mathbf{C}_{\mathbf{1}}\right)$, Cyclipostin $\mathrm{P}\left(\mathbf{C y C}_{\mathbf{1 8 \beta}}\right)$ and its trans diastereoisomer $\left(\mathbf{C y} \mathbf{C}_{\mathbf{1 8 a}}\right)$, Cyclophostin phosphonate analog $\left(\mathbf{C y C}_{2}\right)$, monocyclic enolphosphorus analogs to either Cyclophostin $\left(\mathbf{C y C}_{\mathbf{3 - 1 0} \text {;15-16) }}\right.$ or

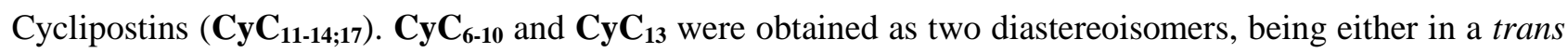
( $\alpha$-isomer) or cis ( $\beta$-isomer) conformation between the OMe on the phosphorus and the H-substituent on the C-5 carbon atom. Adapted from ${ }^{7}$.

Over the last decade, non-tuberculous mycobacterial (NTM) infections have increased worldwide, leading to an emerging public health problem, particularly in industrialized countries, sometimes surpassing tuberculosis. ${ }^{11}$ Among them, M. abscessus represents the most important rapidly growing mycobacteria (RGM). ${ }^{12}$ M. abscessus is indeed responsible for a wide spectrum of clinical syndromes ranging from skin infections to severe pulmonary infections in humans with compromised natural defenses, such as patients with cystic fibrosis (CF). ${ }^{13-14}$ The M. abscessus complex, along with Mycobacterium avium complex, represents over $90 \%$ of all reported NTMpulmonary infection cases in CF patients. ${ }^{15-16}$ Reports also show that $M$. abscessus isolated from CF patients ranged from $16 \%$ and up to $68 \%$ of all isolated NTM. ${ }^{17-19}$ In addition, the presence of $M$. 
abscessus infection prior to lung transplantation represents a risk factor for developing lung infection or a disseminated disease after transplantation. ${ }^{14}$ M. abscessus displays rough $(\mathrm{R})$ and smooth $(\mathrm{S})$ colony morphotypes. ${ }^{20-21}$ The $\mathrm{S}$ morphotype is related to the abundance of the surface-associated glycopeptidolipids (GPL), which is associated with sliding motility and biofilm formation. ${ }^{20}$ In contrast, a remarkable reduction in GPL amount in the cell wall of the R variant was correlated with cord formation. ${ }^{22}$ In addition, $\mathrm{S}$ and $\mathrm{R}$ variants can be considered as two representatives of the same isolate, which may coexist and/or evolve differently in response to host immunity, resulting in different fates for the mycobacteria in its host. ${ }^{20}$ Several studies have confirmed the correlation between colony morphology and virulence. The $\mathrm{S}$ variants are less virulent than $\mathrm{R}$ variants, ${ }^{23}$ which are frequently associated with severe pulmonary infections ${ }^{24-25}$ and are able to persist for years especially in infected CF patients. ${ }^{26}$ In the light of these findings, $M$. abscessus is known to transition from a smooth (S) morphotype with cell surface-associated GPL to a rough (R) morphotype lacking GPL. Accordingly, M. abscessus is notorious for being one of the most drug-resistant mycobacterial species, refractory to standard antimicrobials used for the treatment of Gram-positive and Gramnegative bacteria. ${ }^{27}$ In addition, most antitubercular agents (i.e., rifampin, isoniazid, and ethambutol) are also ineffective against $M$. abscessus, referred to as an "antibiotic nightmare". ${ }^{28}$ This intrinsic polyresistance to drugs results from multiple factors, ${ }^{29}$ including the presence of a highly impermeable cell envelope preventing the penetration of drug, multiple-drug efflux pumps, ${ }^{30-31}$ inability to convert prodrugs into their active metabolites, ${ }^{32}$ expression of numerous enzymes which can modify the drug-target or inactivate the drug itself, ${ }^{27}$ and the acquisition of mutations in the antibiotic targets. Hence, the development of new therapeutic approaches and/or discovery of new chemical entities to fight this pathogen are needed.

Herein, we have synthesized 12 new analogs, i.e. $\mathbf{C y C} \mathbf{1 9}$ to $\mathbf{C y C} \mathbf{3 0}$, by varying the lipophilicity of the $\mathrm{R}^{3}$ chain located on the 7-membered enolphosphorus ring in our phosphate and phosphonate analogs. This structural modification is also supported by the isolation of the anti-malarial Salinipostins, ${ }^{33-34}$ which are essentially Cyclipostins with variations in the enol alkyl substituent. 
Their respective antibacterial activity was further assessed against a panel of pathogenic mycobacteria, including the M. abscessus $\mathrm{R}$ and S variants. Importantly, the MIC of all (26+12) CyCs determined against either extracellular or intracellular M. abscessus growth, revealed the efficacy of eight new candidates. The potential targets of $\mathbf{C y C}_{\mathbf{1 7}}$ and $\mathbf{C y C}_{\mathbf{2 6}}$, the two most potent inhibitors against extracellularly-growing bacteria, were identified via an activity-based protein profiling (ABPP) approach. 


\section{RESULTS AND DISCUSSION}

Synthesis of new Cyclophostin phosphate and phosphonate analogs. We incremented the already available library comprising $26 \mathbf{C y C}$ compounds (i.e., $\mathbf{C y C}_{\mathbf{1 - 1 8}}$ including the cis $^{-}(\alpha)$ and trans- $(\beta)$ isomers), ${ }^{7,} 10$ by synthesizing 12 additional analogs (CyC 19-30) from various 3-keto esters following previously described synthetic routes (Scheme 1). ${ }^{3-6}$

The general approach previously used for the synthesis of phosphonate analogs $\mathbf{C y C} \mathbf{4 - 1 0}$ was applied (Scheme 1A) to the synthesis of cyclic phosphonates with variation in the enol alkyl substituent (CyC19-22). The palladium-catalyzed substitution reaction of methyl or ethyl acetoacetate derivatives $(\mathbf{2})^{35}$ with the allylic carbonate (1) gave the vinyl phosphonates (3) as an $E / Z$ mixture in good yields (35-63\%). The $E$ and $Z$ isomers could be separated by silica gel chromatography, but were generally taken into the next reaction as mixture. Quantitative hydrogenation of (3a-d) led to the saturated phosphonates (4a-d), which after selective demethylation and cyclization gave the racemic forms of monocyclic enolphosphonates (5a-d) corresponding to compounds $\mathbf{C y}_{\mathbf{1 9}}$ to $\mathbf{C y C}_{\mathbf{2 2}}$ (17-62\%, 2 steps).

To optimize the potent observed antibacterial activity of compound $\mathbf{C y C}_{\mathbf{1 7}},{ }^{7,}{ }^{10}$ the synthesis of various monocyclic phosphate analogs has also been completed. Following a literature procedure ${ }^{36-}$ ${ }^{37} \beta$-ketoesters (8a-d) were prepared by alkylation of $t$-butyl acetoacetate derivatives (7a-d) with iodide $(6)^{38}$ (Scheme 1B). The tert-butyl ester was chosen so as to minimize the risk of lactonization upon deprotection of the alcohol function. Reaction of compounds (8a-d) with dimethyl chlorophosphite followed by oxidation of crude material with $I_{2}$ and methanol gave the enolphosphates (9a-d) in modest yield along with recovered starting material $(21-49 \%, 49-81 \%$ BRSM). The 4-methoxybenzyl ether (PMB) protecting group was then removed with 2,3-dichloro5,6-dicyano-1,4-benzoquinone (DDQ) under standard conditions to afford alcohols (10a-d). Demethylation and subsequent cyclization using 1-mesitylene-sulfonyl-3-nitrotriazole (MSNT) gave the monocyclic phosphate tert-butyl esters $\mathbf{C y C}_{27}$ to $\mathbf{C y C}_{30}$ (11a-d). Cleavage of the tert-butyl moiety with TFA in anhydrous conditions followed by $\mathrm{TMSCHN}_{2}$ treatment resulted in the formation of the 
corresponding racemic cyclic enolphosphate methyl esters $\mathbf{C y C}_{23}$ to $\mathbf{C y C}_{26}$ (12a-d) in good yields $(79-100 \%)$.
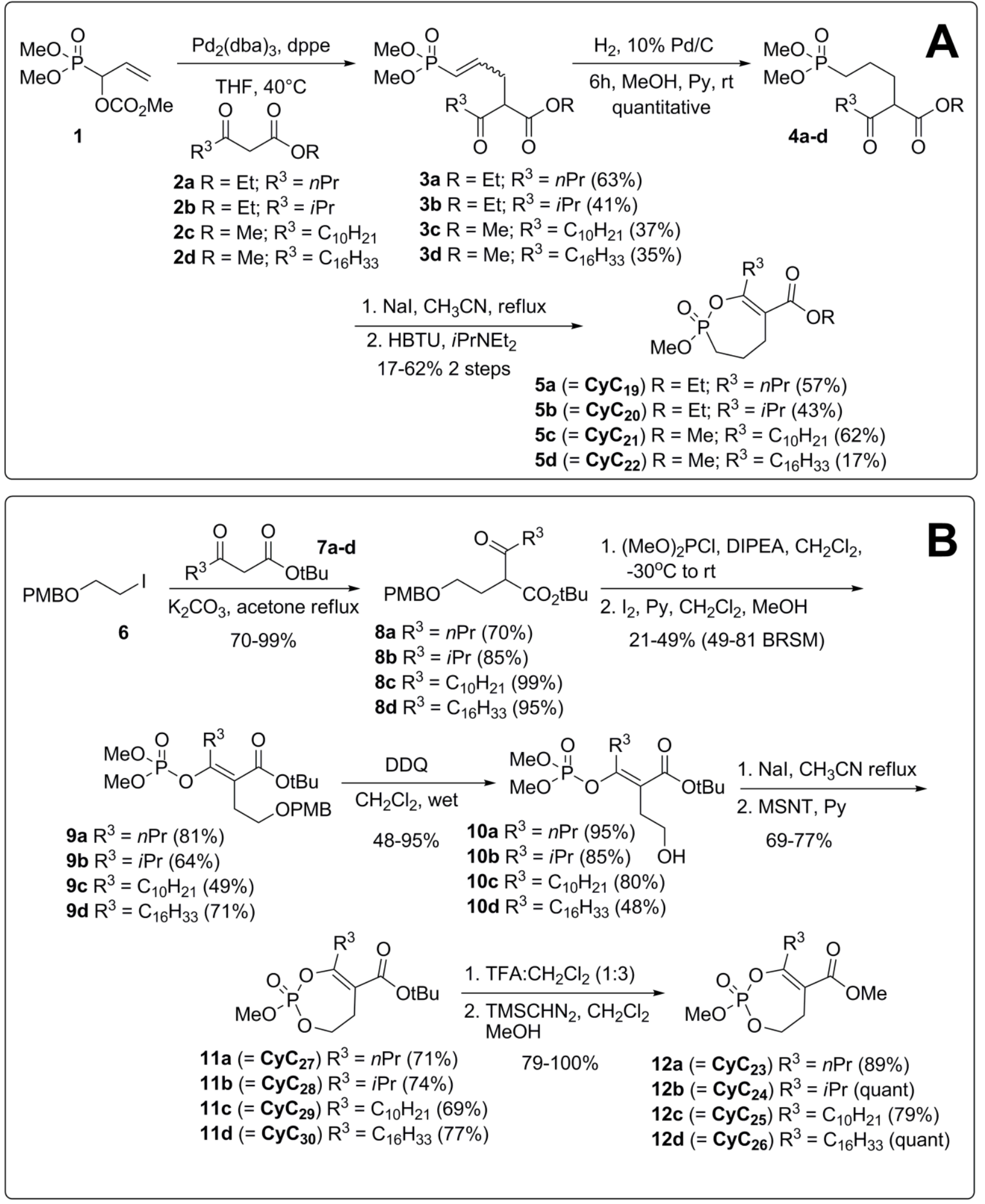

Scheme 1. Synthesis of novel monocyclic enol-phosphonate and -phosphate analogs of Cyclophostin. 
Antibacterial activity of the new $\mathrm{CyC}_{19}-\mathrm{CyC}_{30}$ compounds. The antimicrobial activity of the 12 newly synthesized derivatives was evaluated as previously reported. ${ }^{10}$ Briefly, a preliminary screen on solid medium (30 $\mu \mathrm{M}$ final concentration) was performed on a selected panel of four pathogenic mycobacterial species (i.e., M. marinum, M. bovis BCG, M. tuberculosis $\mathrm{mc}^{2} 6230$, and both S/R variants of M. abscessus) and 2 Gram-negative bacteria (Escherichia coli and Pseudomonas aeruginosa). Following CFU count, 5 out of the 12 CyCs inhibited growth in the range of 50-100\% relative to the positive growth control (i.e., bacteria without antibiotics). Moreover, and as previously observed with $\mathbf{C y C}_{\mathbf{1}}$ to $\mathbf{C y C}_{\mathbf{1 8}},{ }^{10}$ this inhibitory activity was restricted to the four mycobacteria tested, while growth of E. coli and P. aeruginosa was not impacted (see Supplementary Material Table S1). The MIC of these selected $\mathrm{CyC}_{21}, \mathrm{CyC}_{22}, \mathbf{C y C}_{25}, \mathrm{CyC}_{26}$ and $\mathrm{CyC}_{30}$ towards each mycobacterial strain were next determined using the resazurin microtiter assay (REMA) ${ }^{7,10}$ (Table 1). Among the abovementioned CyCs, only $\mathbf{C y C}_{26}$ inhibited growth of M. marinum, M. bovis BCG and M. tuberculosis, with $\mathrm{MIC}_{50}$ values ranging from 1.8 to $26.4 \mu \mathrm{M}$ (Table 1). Interestingly, $\mathbf{C y C}_{21}$ and $\mathbf{C y C}_{22}$ exhibited the best activity (MIC $\mathrm{M}_{50}$ 5.6-8.7 $\mu \mathrm{M}$ ) against $M$. tuberculosis $\mathrm{mc}^{2} 6230$. These latter compounds represent two new potential candidates against this bacterium, therefore extending the first series of $\mathbf{C y C}$ growth inhibitors previously identified. ${ }^{7,10}$

Despite the fact that only $\mathbf{C y C}_{25}$ and $\mathbf{C y C}_{26}$ were active against $M$. abscessus on solid medium (Table 1), we also determined the respective $\mathrm{MIC}_{50}$ values of all $\mathbf{C y C s}$ including the first series of 26 analogs against each S/R variant of $M$. abscessus to investigate deeper their efficiency/selectivity towards this pathogen (see Supplementary Material Table S2). Among the 38 tested compounds including the 12 new synthesized analogs, the best growth inhibitors against M. abscessus $\mathrm{S}$ variant still remained $\mathbf{C y C}_{17}$ and $\mathbf{C y C}_{\mathbf{1 8} \beta}$, which displayed similar $\mathrm{MIC}_{50}$ values (mean $\mathrm{MIC}_{50}=11.7 \pm 0.94$ $\mu \mathrm{M})^{10}$ comparable to that of amikacin (AMK) (Table 1). In all other cases, $\mathrm{MIC}_{50}$ were indicative

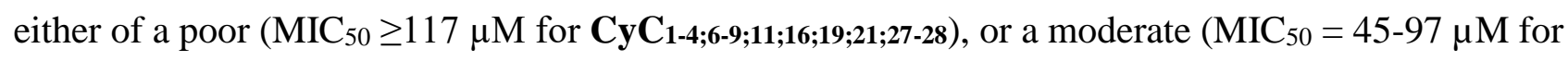
CyC15;18 ;20;22;25-26;29-30) antibacterial activity (see Supplementary Material Table S2). By contrast, nearly all $\mathbf{C y C s}$ were found more active against $M$. abscessus $\mathrm{R}$ variant as compared to the $\mathrm{S}$ variant. 
Although most of the CyCs exhibited quite weak $\mathrm{MIC}_{50}$ in the range 100 to >200 $\mu \mathrm{M}$; eight analogs

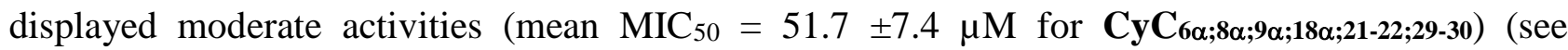
Supplementary Material Table S2). $\mathbf{C y C}_{25}\left(\mathrm{MIC}_{50}=13.9 \mu \mathrm{M}\right)$ and $\mathbf{C y C}_{26}\left(\mathrm{MIC}_{50}=6.9 \mu \mathrm{M}\right)$ were confirmed as very good antimycobacterial molecules, in addition to $\mathbf{C y C}_{17}\left(\mathrm{MIC}_{50}=0.37 \mu \mathrm{M}\right)$ and $\mathbf{C y C}_{18 \beta}\left(\mathrm{MIC}_{50}=8.9 \mu \mathrm{M}\right) .{ }^{10}$ Of interest, these latter four best inhibitors of $M$. abscessus growth were all phosphate esters bearing a long lipophilic C10 / C16 alkyl chain either at the $\mathrm{R}^{1}$ or $\mathrm{R}^{3}$ position (Figure 1 and Scheme 1).

Table 1. Antibacterial activities of the selected active $\mathbf{C y C}$ compounds against four pathogenic mycobacterial strains ${ }^{a}$

\begin{tabular}{|c|c|c|c|c|c|}
\hline \multirow{3}{*}{ Cpds } & \multicolumn{5}{|c|}{$\mathrm{MIC}_{50}(\mu \mathrm{M})$} \\
\hline & \multirow[t]{2}{*}{$\begin{array}{c}M . \text { marinum } \\
\text { ATCC BAA-535/M }\end{array}$} & \multirow[t]{2}{*}{$\begin{array}{c}\text { M. bovis } \\
\text { BCG }\end{array}$} & \multirow[t]{2}{*}{$\begin{array}{l}\text { M. tuberculosis } \\
\text { mc }^{2} 6230\end{array}$} & \multicolumn{2}{|c|}{$\begin{array}{l}\text { M. abscessus } \\
{\text { CIP } 104536^{\mathrm{T}}}^{\text {M. }}\end{array}$} \\
\hline & & & & S variant & $R$ varian \\
\hline AMK & $1.1 \pm 0.05$ & $0.54 \pm 0.03$ & $0.42 \pm 0.02$ & $3.9 \pm 0.19$ & $7.4 \pm 0.26$ \\
\hline INH & $20.5 \pm 0.71$ & $0.71 \pm 0.03$ & $1.5 \pm 0.07$ & $>100$ & $>100$ \\
\hline $\mathrm{CyC}_{17}^{b}$ & $1.5 \pm 0.04$ & $0.54 \pm 0.01$ & $0.55 \pm 0.02$ & $12.7 \pm 0.26$ & $0.37 \pm 0.01$ \\
\hline $\mathrm{CyC}_{18 \beta}{ }^{b}$ & $23.1 \pm 1.07$ & $6.0 \pm 0.29$ & $1.6 \pm 0.07$ & $10.8 \pm 0.43$ & $8.9 \pm 0.09$ \\
\hline $\mathrm{CyC}_{21}$ & $>100$ & $13.8 \pm 0.69$ & $8.7 \pm 0.28$ & $139.0 \pm 4.80$ & $63.0 \pm 0.91$ \\
\hline $\mathrm{CyC}_{22}$ & $>100$ & $24.9 \pm 1.16$ & $5.6 \pm 0.25$ & $65.0 \pm 2.19$ & $51.0 \pm 2.20$ \\
\hline $\mathrm{CyC}_{25}$ & $>100$ & $>100$ & $>100$ & $85.0 \pm 0.86$ & $13.9 \pm 0.56$ \\
\hline $\mathrm{CyC}_{26}$ & $1.8 \pm 0.08$ & $12.4 \pm 0.44$ & $26.4 \pm 0.60$ & $60.0 \pm 2.50$ & $6.9 \pm 0.16$ \\
\hline $\mathrm{CyC}_{30}$ & $>100$ & $14.2 \pm 0.60$ & $>100$ & $62.6 \pm 2.39$ & $57.0 \pm 2.70$ \\
\hline
\end{tabular}

${ }^{a} \mathrm{MIC}_{50}$ corresponding to the concentration leading to $50 \%$ growth inhibition as determined by the REMA assay, are expressed as mean values of two independent assays performed in triplicate $(\mathrm{CV} \%<5 \%)$. ${ }^{b}$ Data for $\mathbf{C y C}_{\mathbf{1 7}}$ and $\mathbf{C y C}_{\mathbf{1 8 \beta}}$ are from ${ }^{10}$. AMK, amikacin. INH, isoniazid.

M. abscessus surface-exposed GPL drives the antibacterial potency of $\mathrm{CyC}$ compounds. From these results, M. abscessus $\mathrm{R}$ appeared to be 6.1- to 34-times more sensitive than M. abscessus $\mathrm{S}$ to $\mathrm{CyC}_{25}, \mathrm{CyC}_{26}$ and $\mathrm{CyC}_{17}$ (Table 1). As previously mentioned, the major difference between these two variants resides in the loss of surface-associated glycopeptidolipids (GPL) in the R form. ${ }^{20,23,39}$ It may be inferred that the GPL covering the surface of $M$. abscessus $\mathrm{S}$ acts as a protective shield 
towards the CyCs, although the natural Cyclipostin P $\mathbf{C y C}_{\mathbf{1 8 \beta}}$ was not strongly affected by the GPL profile.

To confirm the possible relationship between $\mathbf{C y C}$ potency and GPL production, drug susceptibility was assessed using the GPL-deficient $\triangle m m p L 4 b$ mutant generated in an S background of the type strain CIP104536 ${ }^{\mathrm{T}}$, and its complemented counterpart. ${ }^{40-42}$ The $m m p L 4 b$ gene encodes for the MmpL4b membrane protein, which allows translocation of GPL across the plasma membrane. ${ }^{40 \text {, }}$ ${ }^{43}$ Mutations in this gene result in the loss of GPLs and acquisition of a R morphotype. ${ }^{23,40-41}$ Both the wild-type $M$. abscessus $\mathrm{S}$ and the $\triangle m m p L 4 b$ complemented strain responded similarly to $\mathbf{C y C} \mathbf{1 7}$, $\mathrm{CyC}_{25}$ and $\mathrm{CyC}_{26}$, with a more pronounced resistance level to these compounds as compared to the GPL-deficient $\triangle m m p L 4 b$ mutant, which behaved like the wild-type R variant (Figure 2 and Table 2). Accordingly and as observed with $M$. abscessus $\mathrm{S}$ vs. R variant, the $\mathrm{MIC}_{50}$ of $\mathbf{C y C}_{25}, \mathbf{C y C}_{26}$ and $\mathrm{CyC}_{17}$ reached on the $\triangle m m p L 4 b$ complemented strain were 4.8- to 32-times higher than those determined on the $m m p L 4 b$ deletion mutant (Table 2). In contrast, there was a low influence of the GPL content in the activity of $\mathbf{C y C}_{\mathbf{1 8 \beta}}$, as judged by the obtained $\mathrm{MIC}_{50}$ values against different strains (Table 2).

Table 2. Variation of $\mathrm{MIC}_{50}(\mu \mathrm{M})$ of $\mathrm{CyC}_{17}, \mathbf{C y C}_{18 \beta}, \mathbf{C y C}_{25}$ and $\mathbf{C y C}_{26}$ against both $\mathrm{R} \& \mathrm{~S}$ variants of $M$. abscessus as well as mmpL4b mutant strains ${ }^{a}$

\begin{tabular}{|c|c|c|c|c|c|c|}
\hline & \multicolumn{4}{|c|}{$\mathrm{MIC}_{50}(\mu \mathrm{M})$} & \multicolumn{2}{|c|}{ Fold change in $\mathrm{MIC}_{50}$} \\
\hline & $\begin{array}{c}\text { M. abscessus } \\
\text { S }\end{array}$ & $\begin{array}{c}\text { M. abscessus } \\
\text { R }\end{array}$ & $\begin{array}{l}\text { M. abscessus } \\
\text { S_AmmpL4b }\end{array}$ & $\begin{array}{c}\text { M. abscessus } \\
\text { S__mmpL4b::C }\end{array}$ & $\mathrm{R} \rightarrow \mathrm{S}$ & $\begin{aligned} & \Delta m m p L 4 b \\
\rightarrow & \Delta m m p L 4 b:: \mathrm{C}\end{aligned}$ \\
\hline $\mathrm{CyC}_{17}$ & $12.7 \pm 0.26$ & $0.37 \pm 0.01$ & $0.60 \pm 0.03$ & $19.2 \pm 0.62$ & $\times 34.3$ & $\times 32.0$ \\
\hline $\mathrm{CyC}_{18 \beta}$ & $10.8 \pm 0.43$ & $8.9 \pm 0.09$ & $3.3 \pm 0.16$ & $5.4 \pm 0.26$ & $\times 1.2$ & $\times 1.6$ \\
\hline $\mathrm{CyC}_{25}$ & $85.0 \pm 0.86$ & $13.9 \pm 0.56$ & $15.7 \pm 0.73$ & $74.9 \pm 3.4$ & $\times 6.1$ & $\times 4.8$ \\
\hline $\mathrm{CyC}_{26}$ & $60.2 \pm 2.50$ & $6.9 \pm 0.16$ & $7.2 \pm 0.28$ & $67.3 \pm 3.1$ & $\times 8.7$ & $\times 9.3$ \\
\hline
\end{tabular}

${ }^{a} \mathrm{MIC}_{50}$ corresponding to the concentration leading to $50 \%$ growth inhibition as determined by the REMA assay, are expressed as mean values of two independent assays performed in triplicate (CV\% <5\%). 

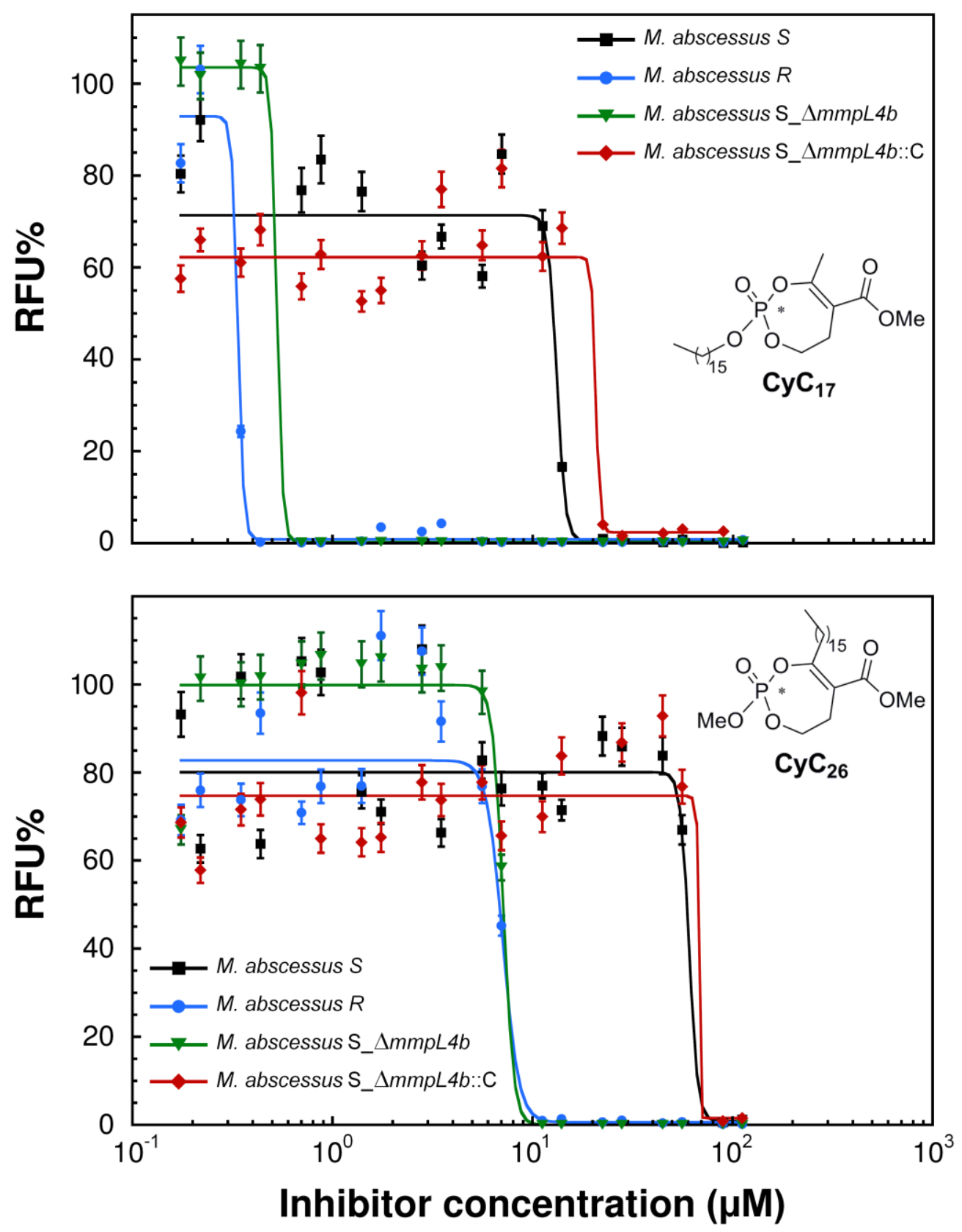

Figure 2. Dose-response activity of $\mathbf{C y C}_{17}$ and $\mathbf{C y C}_{26}$ against $M$. abscessus $\mathrm{S}, \Delta m m p L 4 b$ mutant (M. abscessus $\left.\mathrm{S} \_\Delta m m p L 4 b\right), \Delta m m p L 4 b$ complemented (M. abscessus $\mathrm{S} \_\Delta m m p L 4 b:: \mathrm{C}$ ), and $M$. abscessus $\mathrm{R}$ strains replicating in broth medium, expressed as normalized relative fluorescence units (RFU\%). For each concentration, data are means \pm SD of at least two independent assays performed in duplicate (CV\% $<5 \%)$. 
A significant reduced susceptibility to $\mathbf{C y C}_{17}$ has been reported previously in a $M$. smegmatis__lipg mutant strain in which GPLs were overexpressed due to disruption of lipG, resulting in a change vs. WT in $\mathrm{MIC}_{50}$ value of $\times 15.7$ fold ${ }^{44}$ Both results are also in agreement with a study ${ }^{45}$ reporting that $M$. avium GPL-positive serovar was less sensitive to ethambutol than GPL-negative one, presumably because hydrophobic GPL may alter cell-wall fluidity/permeability and correlate with antibiotic tolerance. ${ }^{45-46}$ Together, these findings underline the importance of the surfaceexposed GPL in the $\mathbf{C y C}$-dependent inhibition of $M$. abscessus growth. Remarkably, $\mathbf{C y C} \mathbf{1 8 \beta}$, which differs from $\mathbf{C y C}_{17}$ by the presence of a butyrolactone ring fused to the seven-membered cyclic phosphate triester (Figure 1), failed to show a high GPL-dependent activity profile. Accordingly, the presence of the lactone may be responsible for this behavior, different from the other monocyclic CyC analogs, towards M. abscessus variants.

Activity-based protein profiling (ABPP) approach for targets identification. In light of our previous study demonstrating the strong affinity of the CyCs for (Ser/Cys)-enzymes bearing a catalytic serine or cysteine residue, ${ }^{4-9,37,47-48}$ we presumed that these inhibitors would also target/impair the activity of enzymes participating in a wide range of physiological processes of the M. abscessus life cycle, resulting in bacterial growth inhibition, as previously shown in $M$. tuberculosis. ${ }^{7}$ Hence, to gain access to their putative targets, activity-based protein profiling (ABPP) ${ }^{7}$ ${ }^{49-50}$ was employed to capture and identify candidate target enzyme(s) impacted by $\mathbf{C y C}_{17}$ and $\mathbf{C y C 2 6}$, the two best hits acting against extracellular M. abscessus.

In the first approach, a crude lysate of $M$. abscessus $\mathrm{R}$ was incubated with either a $\mathbf{C y C}$ inhibitor (or DMSO as a control) and subjected to a competitive probe labeling/enrichment assay with a Desthiobiotin-FP probe (see Supplementary Material Figure S1A). ${ }^{7}$ The enriched mixtures were then digested with trypsin and the resulting peptides analyzed by liquid chromatography-tandem mass spectrometry (LC-MS/MS), followed by subsequent label free quantification analysis. The proteins that were also found in the control experiment (i.e., DMSO alone for unspecific binding to streptavidin-magnetic beads) were discarded. At first, proteins identified with a permutation false 
discovery rate (pFDR) up to $10 \%$ were selected, leading to a panel of 806 distinct protein candidates in the case of $\mathbf{C y C 1 7}$, which was narrowed down to 30 when applying a pFDR of $1 \%$, as compared to only 4 with $\mathbf{C y C}_{26}$ (14 at a pFDR of 10\%) (see Supplementary Material Tables S3-S8).

Given the fact that orthologs typically perform equivalent functions in the respective organisms, ${ }^{51}$ the corresponding orthologs in M. tuberculosis $\mathrm{H} 37 \mathrm{Rv}$ genome of the various identified proteins were reported, adding reliable predictions of the gene functions in terms of essentiality, genomic location and activity. With each inhibitor, except for a few uncharacterized proteins, most of the identified hits were (Ser/Cys)-based enzymes participating in mycobacterial lipid metabolism (see Supplementary Material Tables S4-S5). This was substantiated with $\mathbf{C y C}_{26}$ for which 8 out of 14 identified proteins are (Ser/Cys)-based enzymes. These included the putative $\beta$-lactamase MAB_2833 (i.e., Rv1367c), possibly involved in cell wall biosynthesis; the D-amino acid aminohydrolase MAB_2605c (i.e., Rv2913c) and the probable peptidase MAB_4130 (i.e., Rv0457c); three members of the lipase family Lip, LipH (MAB_2039), LipN (MAB_3270c) and LipW (MAB_0826c); and two Cutinase-like proteins, Cut1 (MAB_3272c) and Cut4 (MAB_3809c). Interestingly the histidinol-phosphate aminotransferase (i.e., MAB_2669c or HisC1), possibly involved in the histidine pathway and annotated as an essential enzyme in M. tuberculosis, ${ }^{52-53}$ was also uncovered with $\mathbf{C y C}_{\mathbf{2 6}}$. All target-proteins of $\mathbf{C y C}_{\mathbf{2 6}}$ were also identified with $\mathbf{C y C} \mathbf{1 7}$, thus confirming this latter as a broader multi-target inhibitor. Given the putative mechanism of action of HisC1 (MAB_2669c) together with the recent resolution of the 3D structure of its M. tuberculosis ortholog Rv1600 in complex with its natural substrate, i.e. pyridoxal-5'-phosphate (PDB id: 4R8D), ${ }^{54}$ one can hypothesize that the two phosphate analogs $\mathbf{C y C}_{17}$ and $\mathbf{C y C}_{26}$ may bind to the active site, thus acting as substrate-like adducts.

In the second approach, the penetration/diffusion of $\mathbf{C y C}_{17}$ inhibitor through the mycobacterial cell wall was taken into account in order to reduce the list of potential targets. Thus, a similar experiment was performed on living bacterial cells. ${ }^{55}$ M. abscessus $\mathrm{R}$ cells were grown to log phase and incubated with $\mathbf{C y C}_{17}$ (or DMSO as a control). After cell lysis, part of the lysate was processed 
Supplementary Material Figure S1B). In parallel, the $\mathbf{C y C} 17$-treated lysate was also incubated with TAMRA-FP to reveal by in-gel fluorescence on an SDS-PAGE scanning, the (Ser/Cys)-enzyme candidates that presumably had reacted with this inhibitor ${ }^{7}$ (see Supplementary Material Figure S1C). At this stage, around 20 distinct bands labeled by TAMRA-FP were detected in the fluorescence readout and also visible by Coomassie staining after release of the enzymes captured by Desthiobiotin-FP (see Supplementary Material Figure S1C-D). In contrast, pre-treatment with $\mathrm{CyC}_{17}$ resulted in a strong decrease in fluorescence intensity of all visible bands; the $\mathbf{C y C}_{17}$-enzyme complex being unable to react with the TAMRA-FP probe. Tryptic digestion followed by tandem mass spectrometry analysis led to the identification of lower numbers of protein candidates as compared to a total lysate; i.e., 39 vs. 208 at a pFDR of 5\%, respectively (Supplementary Material Table S6). It is noteworthy that among these 39 potential hits, 24 were previously detected in the CyC17-treated total lysate (see Supplementary Material Tables S3-4): 16 at a pFDR of 10\%, 1 at a pFDR of $5 \%$, and 7 at a pFDR of $1 \%$; thus implying that 15 proteins had not been detected in the previous treated M. abscessus total lysate, or at least for a pFDR $>10 \%$.

Consistent with previous work involving $\mathbf{C y C}_{17}{ }^{7}$ a variety of hydrolases were detected, including one amidase AmiC (MAB_2181c), two Lip-family members LipI (MAB_2814) and LipT (MAB_3336c), two Cutinase-like proteins Cut1 (MAB_3272c) and Cut3 (MAB_3765), a possible hydrolase (MAB_3034), and MAB_176 (Ag85A) and MAB_177 (Ag85-A/B/C precursor) two members of the antigen 85 (Ag85) complex, which catalyzes the formation of trehalose dimycolate and adds mycolic acids to arabinogalactan ${ }^{9,}$ 56-57 (see Supplementary Material Table S6). Interestingly, 9 out of the 39 identified proteins are annotated as essential enzymes in M. tuberculosis genome (Table 3). ${ }^{52-53}$ Among them, MAB_0172 (i.e., Rv3807c) \& MAB_3612 (i.e., Rv3265c) are possibly involved in the arabinogalactan biosynthesis ${ }^{58-59}$ and MAB_0944 (i.e., Rv0896) is a probable citrate synthase required for the tricarboxylic acid cycle. ${ }^{60}$ 
Table 3. CyC17 target proteins identified in M. abscessus R culture by LC-ESI-MS/MS analysis and annotated as essential ${ }^{a}$ for $M$. tuberculosis orthologs.

\begin{tabular}{|c|c|c|c|c|c|c|}
\hline \multirow[b]{2}{*}{ Protein Ids } & \multirow{2}{*}{$\begin{array}{c}\text { Mol. Weight } \\
{[\text { kDa] }}\end{array}$} & \multicolumn{5}{|c|}{ M. tuberculosis orthologs } \\
\hline & & Rv number & Essentiality & Location $^{b}$ & Activity / Function & $\begin{array}{l}\text { Functional } \\
\text { category }^{c}\end{array}$ \\
\hline MAB_0172 & 19.3 & Rv3807c & Macrophages & $\mathrm{M} ; \mathrm{WCL}$ & Putative decaprenylphosphoryl-5-phosphoribose phosphatase & $\mathrm{CW} / \mathrm{CP}$ \\
\hline MAB_4481 & 28.8 & $\mathrm{Rv} 0224 \mathrm{c}$ & essential gene & WCL & Possible methyltransferase & $\mathrm{IM} / \mathrm{R}$ \\
\hline MAB_3612c & 32.9 & $\operatorname{Rv} 3265 c$ & essential gene & M; WCL & Putative dTDP-rhamnosyltransferase WbbL1 & $\mathrm{CW} / \mathrm{CP}$ \\
\hline MAB_1588c & 39.0 & Rv3230c & in vitro growth & M; WCL & Probable oxidoreductase & $\mathrm{IM} / \mathrm{R}$ \\
\hline MAB_4876c & 45.0 & Rv2017 & in vitro growth & & Transcriptional regulatory protein & $\mathrm{RP}$ \\
\hline MAB_1524c & 46.9 & Rv1232c & essential gene & M; WCL & Uncharacterized protein & - \\
\hline MAB_0944 & 47.6 & Rv0896 & in vitro growth & CW; M; WCL & Probable citrate synthase I GltA2 & $\mathrm{IM} / \mathrm{R}$ \\
\hline MAB_3511c & 74.8 & Rv3198c & essential gene & WCL & Probable ATP-dependent DNA helicase II UvrD2 & IP \\
\hline MAB_2486c & 190.8 & Rv3859c & in vitro growth & CF; CW; WCL & Probable gltB, ferredoxin-dependent glutamate synthase & $\mathrm{IM} / \mathrm{R}$ \\
\hline
\end{tabular}

${ }^{a}$ from $^{52-53}$.

${ }^{b}$ CF: Culture filtrate; CW: Cell wall; M: Membrane fraction; WCL: Whole cell lysate. ${ }^{c}$ IM/R: Intermediary metabolism/respiration; CW/CP: cell wall/cell processes;

LM: Lipid metabolism; V/D/A: Virulence, detoxification, adaptation. 
Of particular interest, the $\mathrm{Ag} 85 \mathrm{~A} / \mathrm{B} / \mathrm{C}$ proteins from $M$. tuberculosis have been recently validated as real targets of $\mathbf{C y C} \mathbf{C 1 7}^{7,9}$ Herein, we confirm that the recombinant M. abscessus Ag85C protein, which shares nearly $60 \%$ amino acid sequence identity with its $M$. tuberculosis ortholog and possesses the same conserved catalytic triad (i.e., $\mathrm{Ser}^{124}-\mathrm{Glu}^{228}-\mathrm{His}^{260}$ ), is also inactivated by $\mathbf{C y C}_{\mathbf{1 7}}$.

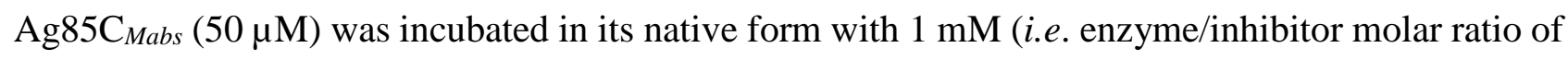
1:20) $\mathbf{C y C}_{17}$ and then treated with $10 \mu \mathrm{M}$ TAMRA-FP fluorescent probe for $1 \mathrm{~h}$. Equal amounts of proteins $(2 \mu \mathrm{g})$ were separated by $12 \%$ SDS-PAGE and visualized by Coomassie staining or in-gel fluorescence for TAMRA detection (see Supplementary Material Figure S2 for details). Quantification of labeling normalized to protein load revealed that pre-incubation with $\mathbf{C y C}_{\mathbf{1 7}}$ resulted in a significant decrease in fluorescence intensity by around $70 \%$ as compared with the nontreated protein. This implies that reaction with the TAMRA probe is strongly impaired in the

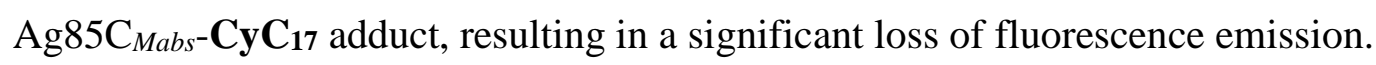

Activity of CyC analogs against intracellular M. abscessus. Similar to M. tuberculosis, following lung infection $M$. abscessus can grow and survive intracellularly inside macrophages. ${ }^{13,20}$ However, MIC values determined in broth medium do not always correlate with the activity of the compounds against intracellular bacteria. Such discrepancy between extra- and intracellular activity has been reported in the case of $M$. tuberculosis with the $\mathbf{C y C s}^{7}$ as well as another family of inhibitors, the Oxadiazolone-core derivatives. ${ }^{55}$ From these findings, all $38 \mathbf{C y C}$ analogs were further tested for their antibacterial activity against $M$. abscessus growth inside infected macrophages.

The cytotoxicity of the 12 new compounds was first assessed using murine Raw 264.7 macrophages. ${ }^{61}$ Except $\mathbf{C y C}_{26}\left(\mathrm{CC}_{50}=50 \mu \mathrm{M}\right)$, all other inhibitors $\mathbf{C y} \mathbf{C}_{\mathbf{1 9 - 2 5} \text {;27-30 }}$ showed very low toxicity towards the cells with $\mathrm{CC}_{50}>100 \mu \mathrm{M}$, similarly to $\mathrm{AMK}\left(\mathrm{CC}_{50} \geq 150 \mu \mathrm{M}\right){ }^{62}$ Taking into account our previous toxicity results obtained with $\mathbf{C y C}_{\mathbf{1 - 1 8}}{ }^{7}$ the 38 synthesized analogs exhibited low cytotoxic towards host mammalian cells.

Due to its high clumping capability, infection with M. abscessus $\mathrm{R}$ results in the lysis of nearly all macrophages at $24 \mathrm{~h}$ post-infection, making it very difficult to quantify in a reliable manner the 
intracellular effect of the CyCs. This is, however, not the case with $M$. abscessus $\mathrm{S}$ which does not aggregate like the $\mathrm{R}$ form, thus enabling the preparation of homogenous and dispersed suspensions. The intracellular growth of $M$. abscessus $\mathrm{S}$ was next assessed following a 24 h exposure of infected Raw264.7 cells to the $\mathbf{C y C}$ compounds at a final concentration of $30 \mu \mathrm{M} .{ }^{63}$ To avoid growth of extracellular mycobacteria, cells were extensively washed and treated with amikacin $(200 \mu \mathrm{g} / \mathrm{mL}=$ $340 \mu \mathrm{M} ; 87 \times \mathrm{MIC}_{50}$ ) prior to treatment with the $\mathbf{C y C}$ analogs. Imipenem (IMP; $80 \mu \mathrm{g} / \mathrm{mL}=267$ $\left.\mu \mathrm{M} ; 67 \times \mathrm{MIC}_{50}\right)$ was used as positive control for this intracellular killing assay. In each case, the viability of infected macrophages was checked by addition of trypan blue ${ }^{64}$ before cell lysis and plating for CFU counting. Nearly all compounds, including the $\mathbf{C y C} \mathbf{C 1 9 - 3 0}$ new series, failed to show an effect at the concentration investigated. In agreement with previous work with M. tuberculosis, ${ }^{7}$ both $(\alpha)$ and $(\beta)$ isomers of $\mathbf{C y C}_{7}$ and $\mathbf{C y C 8}$, which are not active against extracellular bacilli, showed a $40-50 \%$ and $63-65 \%$ decrease in intramacrophagic CFUs $24 \mathrm{~h}$ post infection in the presence of

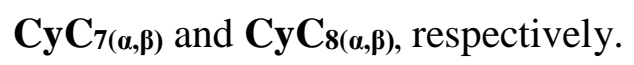

Interestingly, although the phosphate analogs $\mathbf{C y C}_{17}, \mathbf{C y C}_{\mathbf{1 8 \beta}}, \mathbf{C y C}_{25}$ and $\mathbf{C y C}_{26}$ exclusively impaired extracellular growth of M. abscessus, they however remained fully inactive towards infected macrophages. In contrast, the phosphonate analogs $\mathbf{C y C}_{7-8}$ were found active only against intramacrophagic M. abscessus. Similar properties between the phosphonate (i.e., $\mathbf{C y C}_{7-8}$ ) vs. phosphate (i.e., $\mathbf{C y C}_{17}$ ) chemical groups have been reported for $M$. tuberculosis. ${ }^{7}$ In addition, the fact that only $\mathbf{C y C}_{\mathbf{7}(\boldsymbol{\alpha}, \boldsymbol{\beta})}$ and $\mathbf{C y C}_{\mathbf{8}(\boldsymbol{\alpha}, \boldsymbol{\beta})}$ showed a clear preference against intracellularly-replicating mycobacteria may imply that the intracellular mode of action of these CyCs differs from that of CyCs acting exclusively on extracellularly-replicating bacilli. Another hypothesis is that accessibility and/or vulnerability of their corresponding target(s) may be more apparent and crucial during the intracellular lifestyle of M. abscessus. Moreover, a specific stringent response of the macrophage, such as possible host cell metabolism, stimulated by the action of these latter compounds and leading to bacterial clearance cannot, however, be excluded. 
To confirm this screen, $M$. abscessus $\mathrm{S}$ infected macrophages were subjected to a dose-response

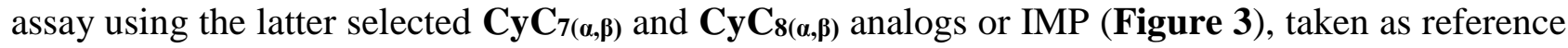
intracellular drug, in order to determine their respective intracellular MIC $_{50 \text { Raw }}$ values (Table 4). Both $\mathrm{CyC}_{7 \boldsymbol{a}}$ and $\mathrm{CyC}_{7 \beta}$ displayed a moderate activity against intracellular $M$. abscessus $\mathrm{S}$ (Figure 3A) with a calculated $\mathrm{MIC}_{50 \mathrm{Raw}}$ of $29.3 \mu \mathrm{M}$ and $65.3 \mu \mathrm{M}$, respectively, similar to that of IMP (MIC 50 Raw $=28.3 \mu \mathrm{M}$ ) used as reference (Table 4). By contrast a 24 h-treatment with either $\mathbf{C y C}_{8 \alpha}$ or $\mathbf{C y} \mathbf{C}_{8 \beta}$ led to a $68.4 \pm 6.4 \%(30-60 \mu \mathrm{M})$ and $73.5 \pm 1.9 \%(60 \mu \mathrm{M})$ reduction in mycobacteria, respectively; which was comparable to that elicited by IMP, i.e., $74.0 \pm 4.4 \%$ reduction following treatment with $60 \mu \mathrm{M}$ (Figure 3C). Regarding $\mathbf{C y C 8 \beta}$, a plateau value corresponding to $64.7 \pm 3.8 \%$ bacterial killing was reached when the infected cells were treated with the compound at a 5-30 $\mu \mathrm{M}$ concentration range. Remarkably, $\mathrm{MIC}_{50 \mathrm{Raw}}$ values of $\mathbf{C y C}_{\mathbf{2} \alpha}(7.9 \mu \mathrm{M})$ as well as $\mathbf{C y C}_{8 \beta}(2.0 \mu \mathrm{M})$ towards intramacrophagic bacilli were 3.6- and 14-fold lower than that of IMP (28.3 $\mu \mathrm{M})$ (Table 4). These

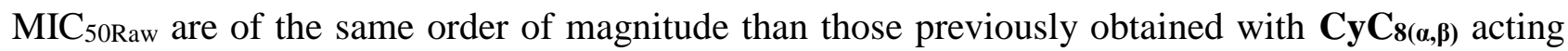
against intracellular M. tuberculosis (i.e., MIC50Raw_Mtb around 4-12 $\mu \mathrm{M}$ ). ${ }^{7}$ The selectivity index (SI $\left.=\mathrm{CC}_{50} / \mathrm{MIC}_{50 \mathrm{Raw}}\right)$ of the four best inhibitors on intracellular M. abscessus vs. Raw264.7 cells was thus found to be in a range from 1.1 and up to 35 for $\mathbf{C y C 8 \beta . ~ O v e r a l l , ~ t h e s e ~ r e s u l t s ~ i n d i c a t e ~ t h a t ~ t h e ~}$ $(\alpha)$ and $(\beta)$ isomers of $\mathbf{C y}_{7}$ and $\mathbf{C y C} \mathbf{C}_{8}$ could enter the macrophages and arrest bacterial replication without exhibiting significant toxicity for the host cell, with comparable effects to IMP. 


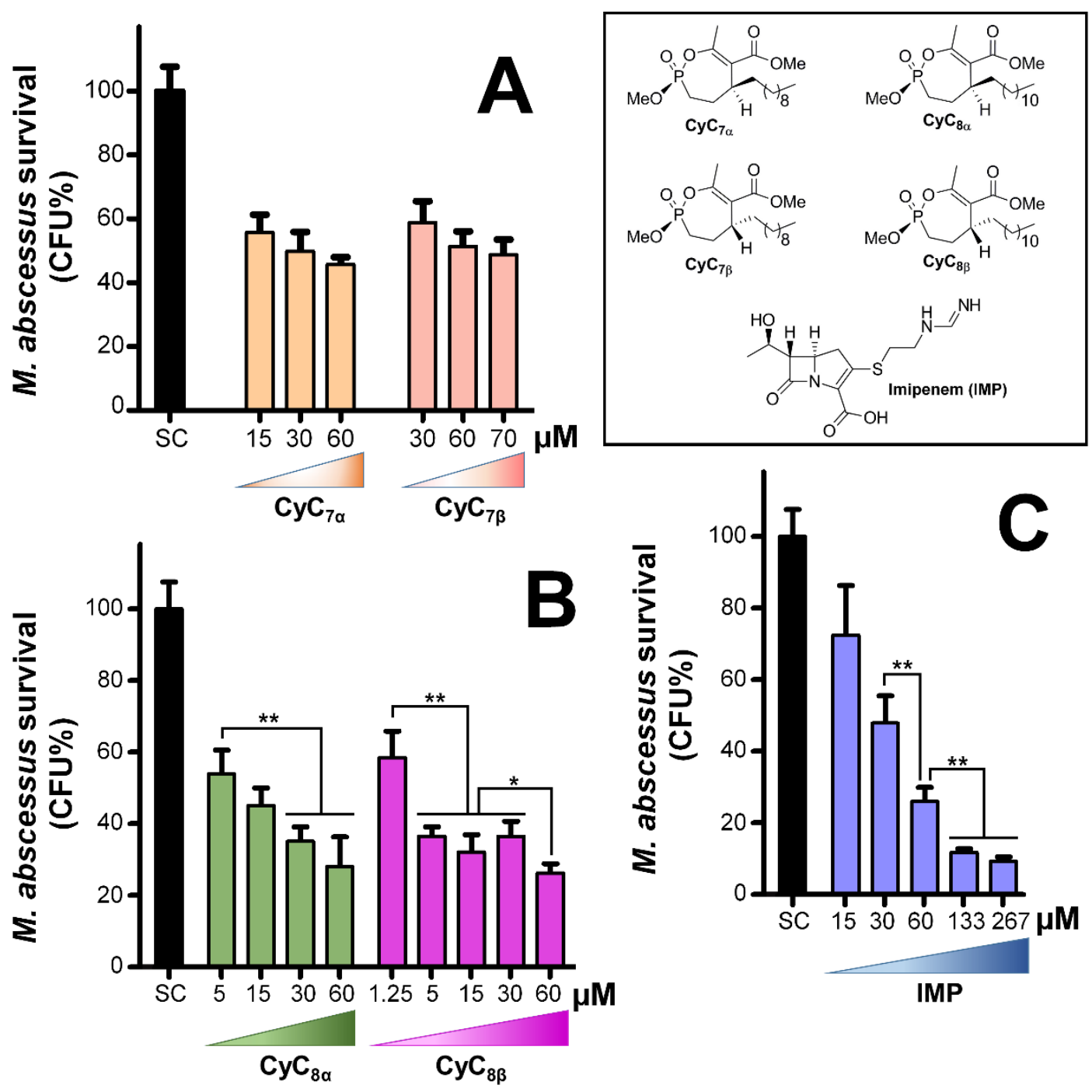

Figure 3. Intracellular activity of (A) $\mathbf{C y C}_{7 \alpha} \& \mathbf{C y C}_{7 \beta}$, and (B) $\mathbf{C y C}_{8 \alpha} \& \mathbf{C y C}_{8 \beta}$ as compared to (C) imipenem (IMP). The activity of selected CyCs on intracellular M. abscessus was tested in Raw264.7 murine macrophages. Cells were infected at a multiplicity of infection (MOI) of 10 with M. abscessus $\mathrm{S}$ variant and treated with various concentrations of each inhibitor or IMP for $24 \mathrm{~h}$. Then, surviving bacteria were enumerated by plating serial dilutions of macrophage lysates. Untreated infected macrophages were used as control representing $100 \%$ of bacterial viability. Results are shown as mean \pm standard error of the mean (SEM) of three independent assays performed in triplicate. SC, solvent control (DMSO). **, $p$-value $<0.01$. $^{*}, p$ value $<0.05$. Statistical analysis was done using a Student's $t$-test. 
Table 4. Antibacterial activities of the most active $\mathbf{C y C}$ analogs against $M$. abscessus $\mathrm{S}$ infected macrophages ${ }^{a}$

\begin{tabular}{lrcr}
\hline \multicolumn{1}{c}{ Compounds } & $\begin{array}{c}\mathbf{C C}_{\mathbf{5 0}} \\
(\boldsymbol{\mu M})\end{array}$ & $\begin{array}{c}\mathbf{M I C}_{\mathbf{5 0 R a w}} \\
(\boldsymbol{\mu M})\end{array}$ & \multicolumn{1}{c}{ SI } \\
\hline $\mathrm{IMP}$ & $\mathrm{ND}$ & $28.3 \pm 4.7$ & - \\
$\mathbf{C y C}_{7 \boldsymbol{\alpha}}$ & $>100$ & $29.3 \pm 2.9$ & $>3.4$ \\
$\mathbf{C y C}_{\mathbf{7 \beta}}$ & $>70$ & $65.3 \pm 6.2$ & $>1.1$ \\
$\mathbf{C y C}_{\mathbf{8} \boldsymbol{a}}$ & $>100$ & $7.9 \pm 0.23$ & $>12.7$ \\
$\mathbf{C y C}_{\mathbf{8 \beta}}$ & $>70$ & $2.0 \pm 0.91$ & $>35$ \\
$\mathbf{C y C}_{\mathbf{1 7}}$ & $>100$ & no effect & - \\
$\mathbf{C y C}_{\mathbf{8 8 \beta}}$ & $>100$ & no effect & - \\
$\mathbf{C y C}_{\mathbf{2 5}}$ & $>100$ & no effect & - \\
$\mathbf{C y C}_{\mathbf{2 6}}$ & $>50$ & no effect & - \\
\hline
\end{tabular}

${ }^{a}$ Experiments were performed as described in Experimental Section. $\mathrm{CC}_{50}$ : compound concentration leading to $50 \%$ Raw264.7 macrophages toxicity. MIC $_{50 \text { Raw }}$ : minimal compound concentration leading to a $50 \%$ decrease in CFU count as compared to untreated cells. Raw264.7 macrophages were infected by M. abscessus $\mathrm{S}$ at a MOI of 10, and further treated with each $\mathbf{C y C}$ or IMP for $24 \mathrm{~h}$. The viable mycobacteria were quantified using the agar plating method. Untreated infected macrophages were used as control representing $100 \%$ of bacterial viability. $\mathrm{MIC}_{50 \mathrm{R} a w}$ were calculated from curve fitting of $\mathrm{CFU} \%$ as a function of the inhibitor concentration. Data are expressed as mean values of three independent assays performed in triplicate. IMP, imipenem. SI, selectivity index: $\mathrm{SI}=\mathrm{CC}_{50} / \mathrm{MIC}_{50 \text { Raw }}$. 


\section{CONCLUSION}

Herein, we have extended our first series of $26 \mathbf{C y C}$ analogs by synthesizing 12 new phosphonate (i.e., $\mathbf{C y C}$ 19-22) and phosphate (i.e., $\mathbf{C y C}_{23-30}$ ) compounds in which we varied the $\mathrm{R}^{3}$ lipophilic chain located on the 7-membered enolphosphorus ring. Evaluation of their antibacterial activity first highlighted $\mathbf{C y}_{21}$ and $\mathbf{C y} \mathbf{C}_{22}$ as two potential candidates against $M$. tuberculosis. With respect to M. abscessus, the MIC determination of this set of $38 \mathbf{C y C s}$ provided $\mathbf{C y C}_{25}$ and $\mathbf{C y C}_{26}$, in addition to $\mathrm{CyC}_{17}$ and $\mathrm{CyC}_{18 \beta}$, as active inhibitors of $\mathrm{R}$ and $\mathrm{S}$ variants. We demonstrated that the absence of surface-exposed GPL in the R variant was responsible for the higher susceptibility to the CyCs as compared to the S strain. The absence of GPL may induce some changes in the cell-wall fluidity/permeability, possibly favoring the penetration/action of these inbhibitors. Putative enzymes targeted by $\mathbf{C y C}_{17}$ or $\mathbf{C y C}_{26}$, the two best extracellular inhibitors, were identified using an $\mathrm{ABPP}$ approach. As anticipated, identified proteins were mainly serine or cysteine enzymes involved in mycobacterial lipid metabolism, among them 11 were annotated as essential enzymes in $M$. tuberculosis genome for in vitro growth or in infected macrophages. When tested against intracellular bacteria, $\mathbf{C y C}_{7(\boldsymbol{\alpha}, \boldsymbol{\beta})}$ and $\mathbf{C y C}_{\mathbf{8}(\boldsymbol{\alpha}, \boldsymbol{\beta})}$ appeared as very potent and promising inhibitors with comparable or even lower $\mathrm{MIC}_{50 \mathrm{R} a w}$ values than that of the standard antibiotics imipenem. Of major interest, such inhibitors were selectively and efficiently acting on major pathogenic mycobacteria inside macrophages, including $M$. tuberculosis ${ }^{7}$ and now also M. abscessus. In addition to their low toxicity towards host cells, the $\mathbf{C y C}$ inhibitors potentially act as multi-target compounds, confirming their potential against one of the most drug-resistant mycobacterial species. It is very likely that blocking simultaneously enzymes involved in various lipid and/or in cell wall biosynthetic pathways would lead to extracellular and/or intracellular inhibition of M. abscessus growth by the selected CyCs. This dual activity of the CyCs is of major importance as it may affect the different stages of the infection process. Moreover, their association with current antibiotics to investigate their potential synergetic activity against resistant $M$. abscessus strains is currently in progress, and could open the way for improving the current treatments against these mycobacterial infections. 


\section{EXPERIMENTAL SECTION}

\section{Chemistry - synthesis of compounds $\mathrm{CyC}_{19}$ to $\mathrm{CyC}_{30}$}

The synthesis of natural Cyclophostin $\mathbf{C y C}_{\mathbf{1}},{ }^{4}$ its phosphonate analogs $\mathbf{C y C}_{\mathbf{2} \alpha}$ and $\mathbf{C y C}_{\mathbf{2} \beta},{ }^{3}$ the monocyclic enolphosphonates $\mathbf{C y C}_{\mathbf{3 - 4}}{ }^{47}$ and the trans- $(\alpha)$ and $\operatorname{cis}-(\beta)$ diastereoisomers $\mathbf{C y C}_{5-10}{ }^{5}$ as well as the trans- $(\alpha)$ and cis- $(\beta)$ Cyclipostin $\mathrm{P} \mathbf{C y C} \mathbf{C 1 8}^{4}$ and the corresponding monocyclic phosphonate $\mathbf{C y C}_{\mathbf{1 1 - 1 3}},{ }^{5,7}$ difluorophosphonate $\mathbf{C y C}_{\mathbf{1 4 - 1 5}}$ and phosphate $\mathbf{C y C}_{\mathbf{1 6 - 1 7}}{ }^{6,37}$ analogs have already been reported. The 12 new analogs $(\mathbf{C y C} \mathbf{C 1 9 - 3 0})$ where synthesized in racemic form from various 3-keto esters following already described synthetic routes (See Supplementary Material for detailed procedures and the full chemical characterization of each new compounds), ${ }^{3-6}$ and have purity of $\geq 95 \%$ as determined by HPLC analysis as reported previously..$^{5}$ The HPLC data were supported by careful analysis of the ${ }^{1} \mathrm{H},{ }^{13} \mathrm{C}$ and particularly the ${ }^{31} \mathrm{P}$ NMR spectra (see Supplementary Material). Stock solutions $(10 \mathrm{mM})$ in which the $\mathbf{C y C}$ compounds were found to be completely soluble in dimethyl sulfoxide (DMSO), were prepared prior to drug susceptibility testing.

\section{Antibacterial evaluation.}

Bacterial strains and growth condition. M. marinum ATCC BAA-535/M, M. bovis BCG Pasteur, M. abscessus CIP104536 ${ }^{\mathrm{T}}$ with either a smooth (S) or rough (R) morphotype, and $M$. tuberculosis $\mathrm{mc}^{2} 6230\left(\mathrm{H} 37 \mathrm{Rv} \triangle R D 1 \Delta\right.$ panCD $\left.{ }^{65}\right)$ strains were routinely grown in Middlebrook $7 \mathrm{H} 9$ broth (BD Difco, Le Pont de Claix, France) supplemented with $0.2 \%$ glycerol, $0.05 \%$ Tween 80 (Sigma-Aldrich, St. Quentin Fallavier, France) and 10\% oleic acid, albumin, dextrose, catalase (OADC enrichment; BD Difco) (7H9-S). In the case of M. tuberculosis mc ${ }^{2} 6230,24 \mu \mathrm{g} / \mathrm{mL} \mathrm{D}$ pantothenate (Sigma-Aldrich) was also added in the 7H9-S medium. All cultures were kept at $37{ }^{\circ} \mathrm{C}$ without shaking, except M. marinum which was grown at $32{ }^{\circ} \mathrm{C}$. Escherichia coli DH10B and Pseudomonas aeruginosa PA01 were grown at $37^{\circ} \mathrm{C}$ in LB Broth Base medium (ThermoFisher Scientific, Illkirch, France). A M. abscessus S mmpL4b KO (M. abscessus S_AmmpL4b) mutant displaying an $\mathrm{R}$ morphotype ${ }^{40}$ and its complemented counterpart (M. abscessus $\left.\mathrm{S} \_\Delta m m p L 4 b:: \mathrm{C}\right)$, 
which stably expresses MmpL4b under the control of the hsp60 promoter, were also used as previously reported $\mathrm{in}^{20}$.

Antibiotics. Amikacin was purchased from Euromedex (Souffelweyersheim, France), and imipenem was provided by Mylan (Saint-Priest, France). Stock solution in water were freshly prepared for each experiment and filtered through a sterilized $0.22-\mu \mathrm{m}$-pore-size polycarbonate syringe filter (Millipore, Saint-Quentin-en-Yvelines, France).

Drug susceptibility testing on solid medium. This was performed in 24-well suspension culture plates (Greiner bio-one) as described previously. ${ }^{66}$ E. coli and P. aeruginosa were grown on LB agar medium at $37{ }^{\circ} \mathrm{C}$. All mycobacteria were grown at either $32{ }^{\circ} \mathrm{C}($ M. marinum $)$ or $37^{\circ} \mathrm{C}($ M. abscessus, M. bovis BCG and M. tuberculosis $\mathrm{mc}^{2}$ 6230) on Middlebrook 7H10 agar (BD Difco) supplemented with $10 \% \mathrm{OADC}$, and $24 \mu \mathrm{g} / \mathrm{mL}$ D-pantothenate (M. tuberculosis $\mathrm{mc}^{2} 6230$ ). The wells were filled with $1 \mathrm{~mL}$ of the appropriate medium containing each of the $\mathbf{C y C}_{19}-\mathbf{C y C}_{\mathbf{3 0}}$ analogs at a single $30 \mu \mathrm{M}$ final concentration. Each screening plate contained negative (DMSO) and positive (50 $\mu \mathrm{M}$ antibiotics) controls, as well as one well for sterility control (i.e., medium alone). For the $100 \%$ inhibition control we used $50 \mu \mathrm{M}$ amikacin (Sigma Aldrich) for M. marinum, M. abscessus, M. bovis BCG, M. tuberculosis $\mathrm{mc}^{2} 6230$ and E. coli; and $50 \mu \mathrm{M}$ carbenicillin (Sigma Aldrich) for $P$. aeruginosa. Each well was spotted with $10 \mu \mathrm{L}$ of a bacterial culture at $5 \times 10^{5}$ cells $/ \mathrm{mL}$. Colonies were counted after 1 day to 2 weeks of incubation at $37^{\circ} \mathrm{C}$, depending on the strain tested, to check bacterial viability. The $\mathbf{C y C}$ compounds leading to a minimum of 50\% growth inhibition from $\mathrm{CFU}$ count were selected for subsequent MIC determination using the REMA assay.

Resazurin microtiter assay (REMA) for MIC determination. The concentrations of compound leading to bacterial growth inhibition were first determined using the resazurin microtiter assay (REMA). ${ }^{7,10,55}$ Briefly, log-phase bacteria were diluted to a cell density of $5 \times 10^{6}$ cells $/ \mathrm{mL}$ and 100 $\mu \mathrm{L}$ of this inoculum was grown in a 96-well plate in the presence of serial dilutions of compounds. After 7-14 days incubation, $20 \mu \mathrm{L}$ of a $0.025 \%(w / v)$ resazurin solution was added to each well (200 $\mu \mathrm{L}$ ) and incubation was continued until the appearance of a color change (from blue to pink) in the 
control well (bacteria without antibiotics). Fluorescence of the resazurin metabolite resorufin ( $\lambda_{\text {excitation, }} 530 \mathrm{~nm} ; \lambda_{\text {emission, }} 590 \mathrm{~nm}$ ) was then measured, ${ }^{7,10,55}$ and the concentration leading to $50 \%$ growth inhibition was defined as the $\mathrm{MIC}_{50}$. See Supplementary Material for detailed protocol.

Determination of cytotoxic activity for new $C_{y} C_{19-} C_{y} C_{30}$ analogs (resazurin assay). The cytotoxicity of compounds against eukaryotic cells was measured based on the reduction of resazurin $^{61,63}$ as a value of cellular viability by metabolic activity. Murine (Raw264.7) macrophages (American Type Culture Collection TIB-71) were cultured from a freezer stock in Dulbecco's modified Eagle medium (DMEM; Gibco) supplemented with 10\% heat-inactivated fetal calf serum (FBS, Invitrogen) $\left(\mathrm{DMEM}^{\mathrm{FBS}}\right)$. Cells were grown at $37^{\circ} \mathrm{C}$ and $5 \% \mathrm{CO}_{2}$ to subconfluent concentrations, then $1 \times 10^{5}$ cells/well were seeded in 96-well flat-bottom Nunclon Delta Surface microplates with lid (ThermoFisher Scientific, ref. 167008) in a final volume of $200 \mu \mathrm{L}$ per well and cultured for additional $24 \mathrm{~h}$. The medium was removed by aspiration, and $200 \mu \mathrm{L}$ of serial two-fold dilution of each compound $\left(\mathbf{C y C}_{19}\right.$ to $\left.\mathbf{C y C}_{\mathbf{3 0}}\right)$ in $\mathrm{DMEM}^{\mathrm{FBS}}$ were then added to each well. After $24 \mathrm{~h}$ incubation, $20 \mu \mathrm{L}$ of a $0.025 \%(w / v)$ resazurin solution was added to each well. Fluorescence was measured following a 4-h incubation at $37{ }^{\circ} \mathrm{C}$ and $5 \% \mathrm{CO}_{2}$ in the dark, by excitation at $530 \mathrm{~nm}$ and emission at $590 \mathrm{~nm}$ as described above, leading to relative metabolic activities. Addition of DMSO was used as $100 \%$ viability reference and addition of $0.2 \%$ Triton $\mathrm{X}-100$ solution served as negative standard (0\% viability). All experiments were performed as two independent triplicates.

Intramacrophage killing assay. Murine (Raw264.7) macrophages (American Type Culture Collection TIB-71) were grown in $\mathrm{DMEM}^{\mathrm{FBS}}$ medium at $37^{\circ} \mathrm{C}$ and $5 \% \mathrm{CO}_{2}$ to subconfluent concentrations, then $5 \times 10^{4}$ cells/well were seeded in 96-well flat-bottom Nunclon Delta Surface microplates with lid (ThermoFisher Scientific, ref. 167008) in a final volume of $200 \mu \mathrm{L}$ per well and cultured for additional $24 \mathrm{~h}$. The cells were infected with M. abscessus $\mathrm{S}$ at a multiplicity of infection (MOI) of 1:10 and incubated at $37{ }^{\circ} \mathrm{C}$ in the presence of $5 \% \mathrm{CO}_{2}$ for $3 \mathrm{~h}$. Cells were then washed three times with DMEM then refed with DMEM ${ }^{\mathrm{FBS}}$ supplemented with $200 \mu \mathrm{g} / \mathrm{mL}$ amikacin for $1 \mathrm{~h}$. at $37^{\circ} \mathrm{C}$ and $5 \% \mathrm{CO}_{2}$ to kill all extra-cellular bacteria; washed again three times with DMEM prior 
to the addition of 2-fold dilutions of $\mathbf{C y C}$ compounds or imipenem (IMP) in DMEM ${ }^{\mathrm{FBS}}$ supplemented with $50 \mu \mathrm{g} / \mathrm{mL}$ (i.e., $85.4 \mu \mathrm{M}$ ) amikacin (200 $\mu \mathrm{L}$ final volume). In each plate, negative controls consisting of amikacin $(50 \mu \mathrm{g} / \mathrm{mL})$ and 1\% DMSO (i.e., infected macrophages only); as well as positive controls containing amikacin $(50 \mu \mathrm{g} / \mathrm{mL})$ plus $80 \mu \mathrm{g} / \mathrm{mL}$ (i.e., $267 \mu \mathrm{M})$ IMP were also included. Plates were incubated for $24 \mathrm{~h}$ at $37{ }^{\circ} \mathrm{C}, 5 \% \mathrm{CO}_{2}$. Cells were washed three times with PBS and lysed by adding $200 \mu \mathrm{L}$ of $0.1 \%$ Triton X-100. Serial dilutions of each culture were then plated at least in duplicate on 7H9 agar medium. Colonies were counted after 4 to 5 days of incubation at $37^{\circ} \mathrm{C}$ to check intracellular bacterial viability following treatment with each compound concentration. DMSO-treated infected macrophages corresponded as control representing $100 \%$ of bacterial viability. Intracellular $\mathrm{MIC}_{\mathrm{Raw}}$ values were determined by fitting the $\mathrm{CFU} \%$ sigmoidal doseresponse curves in Kaleidagraph 4.2 software (Synergy Software). The lowest compound concentration inhibiting $50 \%$ of intracellular bacterial growth was defined as the $\mathrm{MIC}_{50 \mathrm{Raw}}$. Experiments were done three times independently.

\section{$\mathrm{CyC}_{17}$ and $\mathrm{CyC}_{26}$ target enzymes identification.}

Activity-based protein profiling (ABPP). Homogeneous bacterial suspension of M. abscessus $\mathrm{R}$ in $7 \mathrm{H} 9-\mathrm{S}$ was adjusted at an $\mathrm{OD}_{600}$ of 40 and then incubated with the selected $\mathbf{C y C}_{17}$ or $\mathbf{C y C}_{26}$ inhibitor (400 $\mu \mathrm{M}$ final concentration) or DMSO (control) at $37{ }^{\circ} \mathrm{C}$ for $2-3 \mathrm{~h}$. under gentle shaking at $75 \mathrm{rpm}$. Bacteria were then washed 3 times with PBS containing $0.05 \%$ Tween 80, resuspended in PBS buffer at a 1:1 $(w / v)$ ratio and then lysed by mechanical disruption on a BioSpec Beadbeater. Both CyC-treated M. abscessus and DMSO-control lysate samples ( $750 \mu \mathrm{L}-0.75 \mathrm{mg}$ total proteins) were labeled with $2 \mu \mathrm{M}$ Desthiobiotin-FP probe for $90 \mathrm{~min}$ at room temperature. Samples were enriched for biotinylated proteins using Nanolink streptavidin magnetic beads $0.8 \mu \mathrm{m}$ (Solulink), according to the manufacturer's instructions. The resulting captured biotinylated proteins solution was mixed with $5 \mathrm{X}$ Laemmli reducing sample buffer, and heated at $95{ }^{\circ} \mathrm{C}$ for $5 \mathrm{~min}$. The released denatured proteins were subjected to tryptic digestion, peptide extraction, and LC-MS/MS analysis as described below. Alternatively, the CyC-treated M. abscessus and DMSO-control lysate samples 
(100 $\mu \mathrm{L}-100 \mu \mathrm{g}$ total proteins) were incubated with $2 \mu \mathrm{M}$ ActivX TAMRA-FP probe (Thermo Fisher Scientific) for $90 \mathrm{~min}$ at room temperature and in absence of light. The reaction was stopped by adding $4 \mathrm{X}$ Laemmli reducing sample buffer and boiling at $95{ }^{\circ} \mathrm{C}$ for $5 \mathrm{~min}$. The labeled proteins were further separated by SDS-PAGE electrophoresis. TAMRA fluorescence (TAMRA: $\lambda_{\mathrm{ex}} 557 \mathrm{~nm}$, $\lambda_{\mathrm{em}} 583 \mathrm{~nm}$ ) was detected using a ChemiDoc MP Imager (Bio-Rad).

Detailed Material and Methods regarding ABPP experiments is given in Supplementary Material.

Protein identification and quantification. Protein extract were loaded and stacked on a NuPAGE gel (Life Technologies). Stained bands were submitted to an in-gel trypsin digestion. ${ }^{67}$ Peptides extracts were reconstituted with $0.1 \%$ trifluoroacetic acid in $4 \%$ acetonitrile and analyzed by liquid chromatography (LC)-tandem mass spectrometry (MS/MS) using a LTQ-Orbitrap Velos Mass Spectrometer (Thermo Electron, Bremen, Germany) online with a nanoLC Ultimate 3000 chromatography system (Dionex, Sunnyvale, CA). Protein identification and quantification were processed using the MaxQuant computational proteomics platform, version 1.5.3.8 ${ }^{68}$ using a UniProt M. abscessus ATCC 19977 (Taxon 561007) database (date 2018.01; 4940 entries). The statistical analysis was done with Perseus program (version 1.5.6.0). Differential proteins were detected using a two-sample $t$-test at 0.01 and 0.05 permutation based FDR. The mass spectrometry proteomics data have been deposited to the ProteomeXchange Consortium (www.proteomexchange.org) ${ }^{69}$ via the PRIDE partner repository with the dataset identifier PXD014255.

Detailed Material and Methods is given in Supplementary Materials. 


\section{ANCILLARY INFORMATION.}

Supporting Information: The Supporting Information is available free of charge on the ACS Publications website.

Detailed protocols, full chemical characterization, NMR spectra and HPLC chromatograms of all new CyC compounds; detailed protocols regarding the MIC determination and targets identification; Figure S1 (Activity based protein profiling workflow for the identification of the proteins covalently bound to each $\mathbf{C y C}$ inhibitor) and Figure $\mathbf{S 2}$ (Inhibition of the $\mathrm{Ag} 85 \mathrm{C}_{\text {Mabs }}$ by $\mathbf{C y C} \mathbf{1 7}$ ); Table $\mathbf{S 1}$ (antimicrobial susceptibility testing of the new series of 12 CyCs by the agar plate method) and Table S2 (Extracellular antibacterial activities of all $\mathbf{C y C}$ analogs against both $\mathrm{R} \& \mathrm{~S}$ variants of $M$. abscessus). (PDF)

Tables S3-S8: $\mathbf{C y C}_{17}$ and $\mathbf{C y C}_{26}$ target proteins identified in $M$. abscessus $\mathrm{R}$ total lysate and in culture cell by LC-ESI-MS/MS analysis, and full dataset from the proteomics analysis. (XLSX)

\section{AUTHOR INFORMATION}

\section{Corresponding Author Information}

* JFC: e-mail: jfcavalier@ imm.cnrs.fr. ORCID 0000-0003-0864-8314

*CDS: e-mail: SpillingC@msx.umsl.edu.

\section{Author Contributions}

$\S \mathrm{AM}$ and JNR contributed equally to this work.

CDS, SC and JFC conceived and designed the experiments. JNR, BPM, RRP, AAB and CDS provided chemical compounds. AM, VLM and SA performed the experiments. AM, SA, LC, CDS, SC and JFC contributed to data analysis and interpretation. AM, JNR, JLH, LK, CDS, SC and JFC wrote the manuscript. All authors have given approval to the final version of the manuscript.

\section{Notes}

The authors declare no competing financial interest. 


\section{ACKNOWLEDGEMENTS}

This work was supported by the CNRS and Aix Marseille University. A. Madani was supported by a PhD fellowship from the Association Grégory Lemarchal and Vaincre la Mucoviscidose (projet $\left.\mathrm{n}^{\circ} \mathrm{RF} 20160501651\right)$. Proteomics analyses were supported by the Institut Paoli-Calmettes and the Centre de Recherche en Cancérologie de Marseille. Proteomic analyses were done using the mass spectrometry facility of Marseille Proteomics (marseille-proteomique.univ-amu.fr) supported by IBISA (Infrastructures Biologie Santé et Agronomie), the Cancéropôle PACA, the Provence- AlpesCôte d'Azur Region, the Institut Paoli-Calmettes, and the Centre de Recherche en Cancérologie de Marseille. The authors wish to thank Saroj Kafle and Dr. Bruce Hamper for performing HPLC analysis of CyC compounds.

\section{ABBREVIATIONS USED}

ABPP, activity-based protein profiling; $\mathrm{AMK}$, amikacin; $\mathrm{CC}_{50}$, compound concentration leading to $50 \%$ of cell cytotoxicity; CF, cystic fibrosis; CFU, colony-forming units; CyC, Cyclipostins \& Cyclophostin analogs; GPL, glycopeptidolipids; IMP, imipenem; INH, isoniazid; MIC50, minimal inhibitory concentration leading to $50 \%$ of growth inhibition; NTM, non-tuberculous mycobacterial; pFDR, permutation false discovery rate; REMA, resazurin microtiter assay; RFU\%, relative fluorescence units. 


\section{REFERENCES}

1. Kurokawa, T.; Suzuki, K.; Hayaoka, T.; Nakagawa, T.; Izawa, T.; Kobayashi, M.; Harada, N., Cyclophostin, acetylcholinesterase inhibitor from Streptomyces lavendulae. J. Antibiot. (Tokyo) 1993, 46 (8), 1315-1318. DOI: https://doi.org/10.7164/antibiotics.46.1315.

2. Seibert, G.; Toti, L.; Wink, J. Treating mycobacterial infections with cyclipostins. WO/2008/025449, March 06, 2008, 2008.

3. Bandyopadhyay, S.; Dutta, S.; Spilling, C. D.; Dupureur, C. M.; Rath, N. P., Synthesis and Biological Evaluation of a Phosphonate Analog of the Natural Acetyl Cholinesterase Inhibitor Cyclophostin. J. Org. Chem. 2008, 73 (21), 8386-8391. DOI: https://doi.org/10.1021/jo801453v.

4. Malla, R. K.; Bandyopadhyay, S.; Spilling, C. D.; Dutta, S.; Dupureur, C. M., The First Total Synthesis of $( \pm)$-Cyclophostin and $( \pm)$-Cyclipostin P: Inhibitors of the Serine Hydrolases Acetyl Cholinesterase and Hormone Sensitive Lipase. Org. Lett. 2011, 13 (12), 3094-3097. DOI: https://doi.org/10.1021/ol200991x.

5. Point, V.; Malla, R. K.; Diomande, S.; Martin, B. P.; Delorme, V.; Carriere, F.; Canaan, S.; Rath, N. P.; Spilling, C. D.; Cavalier, J. F., Synthesis and kinetic evaluation of cyclophostin and cyclipostins phosphonate analogs as selective and potent inhibitors of microbial lipases. $J$ Med Chem 2012, 55 (22), 10204-10219. DOI: https://doi.org/10.1021/jm301216x.

6. Vasilieva, E.; Dutta, S.; Malla, R. K.; Martin, B. P.; Spilling, C. D.; Dupureur, C. M., Rat hormone sensitive lipase inhibition by cyclipostins and their analogs. Bioorg Med Chem. 2015, 23 (5), 944-952. DOI: http://dx.doi.org/10.1016/j.bmc.2015.01.028.

7. Nguyen, P. C.; Delorme, V.; Bénarouche, A.; Martin, B. P.; Paudel, R.; Gnawali, G. R.; Madani, A.; Puppo, R.; Landry, V.; Kremer, L.; Brodin, P.; Spilling, C. D.; Cavalier, J.-F.; Canaan, S., Cyclipostins and Cyclophostin analogs as promising compounds in the fight against tuberculosis. Scientific Reports 2017, 7 (1), 11751. DOI: https://doi.org/10.1038/s41598-017-11843-4.

8. Nguyen, P. C.; Nguyen, V. S.; Martin, B. P.; Fourquet, P.; Camoin, L.; Spilling, C. D.; Cavalier, J.-F.; Cambillau, C.; Canaan, S., Biochemical and structural characterization of TesA, a 
major thioesterase required for outer-envelope lipid biosynthesis in M. tuberculosis. J Mol Biol. 2018, 430 (24), 5120-5136. DOI: https://doi.org/10.1016/j.jmb.2018.09.017.

9. Viljoen, A.; Richard, M.; Nguyen, P. C.; Fourquet, P.; Camoin, L.; Paudal, R. R.; Gnawali, G. R.; Spilling, C. D.; Cavalier, J.-F.; Canaan, S.; Blaise, M.; Kremer, L., Cyclipostins and Cyclophostin analogs inhibit the antigen 85C from Mycobacterium tuberculosis both in vitro and in vivo. J. Biol. Chem. 2018, 293 (8), 2755-2769. DOI: https://doi.org/10.1074/jbc.RA117.000760.

10. Nguyen, P. C.; Madani, A.; Santucci, P.; Martin, B. P.; Paudel, R. R.; Delattre, S.; Herrmann, J.-L.; Spilling, C. D.; Kremer, L.; Canaan, S.; Cavalier, J.-F., Cyclophostin and cyclipostins analogs, new promising molecules to treat mycobacterial-related diseases. Int J Antimicrob. Agents 2018, 51, 651-654. DOI: https://doi.org/10.1016/j.ijantimicag.2017.12.001.

11. Chou, M. P.; Clements, A. C. A.; Thomson, R. M., A spatial epidemiological analysis of nontuberculous mycobacterial infections in Queensland, Australia. BMC Infect Dis. 2014, 14, 279279. DOI: https://doi.org/10.1186/1471-2334-14-279.

12. Ryan, K.; Byrd, T. F., Mycobacterium abscessus: Shapeshifter of the Mycobacterial World. Frontiers Microbiol. 2018, 9, 2642-2642. DOI: https://doi.org/10.3389/fmicb.2018.02642.

13. Wu, M.-L.; Aziz, D. B.; Dartois, V.; Dick, T., NTM drug discovery: status, gaps and the way forward. Drug Discov Today 2018, $23 \quad$ (8), $\quad 1502-1519 . \quad$ DOI: https://doi.org/10.1016/j.drudis.2018.04.001.

14. Osmani, M.; Sotello, D.; Alvarez, S.; Odell, J. A.; Thomas, M., Mycobacterium abscessus infections in lung transplant recipients: 15-year experience from a single institution. Transpl Infect Dis. 2018, 20 (2), e12835. DOI: https://doi.org/10.1111/tid.12835.

15. Ryu, Y. J.; Koh, W.-J.; Daley, C. L., Diagnosis and Treatment of Nontuberculous Mycobacterial Lung Disease: Clinicians' Perspectives. Tuberc Respir Dis 2016, 79 (2), 74-84. DOI: https://doi.org/10.4046/trd.2016.79.2.74.

16. van Ingen, J.; Wagner, D.; Gallagher, J.; Morimoto, K.; Lange, C.; Haworth, C. S.; Floto, R. A.; Adjemian, J.; Prevots, D. R.; Griffith, D. E., Poor adherence to management guidelines in 
nontuberculous mycobacterial pulmonary diseases. Eur. Respir. J. 2017, 49 (2). DOI: https://doi.org/10.1183/13993003.01855-2016.

17. Pierre-Audigier, C.; Ferroni, A.; Sermet-Gaudelus, I.; Le Bourgeois, M.; Offredo, C.; VuThien, H.; Fauroux, B.; Mariani, P.; Munck, A.; Bingen, E.; Guillemot, D.; Quesne, G.; Vincent, V.; Berche, P.; Gaillard, J. L., Age-related prevalence and distribution of nontuberculous mycobacterial species among patients with cystic fibrosis. J Clin Microbiol. 2005, 43 (7), 3467-70. DOI: https://doi.org/10.1128/JCM.43.7.3467-3470.2005.

18. Roux, A. L.; Catherinot, E.; Ripoll, F.; Soismier, N.; Macheras, E.; Ravilly, S.; Bellis, G.; Vibet, M. A.; Le Roux, E.; Lemonnier, L.; Gutierrez, C.; Vincent, V.; Fauroux, B.; Rottman, M.; Guillemot, D.; Gaillard, J. L., Multicenter study of prevalence of nontuberculous mycobacteria in patients with cystic fibrosis in France. J Clin. Microbiol. 2009, 47 (12), 4124-8. DOI: https://doi.org/10.1128/JCM.01257-09.

19. Lim, A. Y. H.; Chotirmall, S. H.; Fok, E. T. K.; Verma, A.; De, P. P.; Goh, S. K.; Puah, S. H.; Goh, D. E. L.; Abisheganaden, J. A., Profiling non-tuberculous mycobacteria in an Asian setting: characteristics and clinical outcomes of hospitalized patients in Singapore. BMC Pulm Med. 2018, 18 (1), 85-85. DOI: https://doi.org/10.1186/s12890-018-0637-1.

20. Roux, A. L.; Viljoen, A.; Bah, A.; Simeone, R.; Bernut, A.; Laencina, L.; Deramaudt, T.; Rottman, M.; Gaillard, J. L.; Majlessi, L.; Brosch, R.; Girard-Misguich, F.; Vergne, I.; de Chastellier, C.; Kremer, L.; Herrmann, J. L., The distinct fate of smooth and rough Mycobacterium abscessus variants inside macrophages. Open Biol. 2016, 6 (11), 160185. DOI: https://doi.org/10.1098/rsob.160185.

21. Gutierrez, A. V.; Viljoen, A.; Ghigo, E.; Herrmann, J. L.; Kremer, L., Glycopeptidolipids, a Double-Edged Sword of the Mycobacterium abscessus Complex. Front Microbiol. 2018, 9, 1145. DOI: https://doi.org/10.3389/fmicb.2018.01145.

22. Sanchez-Chardi, A.; Olivares, F.; Byrd, T. F.; Julian, E.; Brambilla, C.; Luquin, M., Demonstration of cord formation by rough Mycobacterium abscessus variants: implications for the 
clinical microbiology laboratory. $J$ Clin Microbiol. 2011, 49 (6), 2293-5. DOI: https://doi.org/10.1128/JCM.02322-10.

23. Nessar, R.; Reyrat, J. M.; Davidson, L. B.; Byrd, T. F., Deletion of the mmpL4b gene in the Mycobacterium abscessus glycopeptidolipid biosynthetic pathway results in loss of surface colonization capability, but enhanced ability to replicate in human macrophages and stimulate their innate immune response. Microbiology 2011, 157 (Pt 4), 1187-95. DOI: https://doi.org/10.1099/mic.0.046557-0.

24. Catherinot, E.; Clarissou, J.; Etienne, G.; Ripoll, F.; Emile, J. F.; Daffe, M.; Perronne, C.; Soudais, C.; Gaillard, J. L.; Rottman, M., Hypervirulence of a rough variant of the Mycobacterium abscessus type strain. Infect Immun 2007, 75 (2), 1055-8. DOI: https://doi.org/10.1128/IAI.0083506.

25. Catherinot, E.; Roux, A. L.; Macheras, E.; Hubert, D.; Matmar, M.; Dannhoffer, L.; Chinet, T.; Morand, P.; Poyart, C.; Heym, B.; Rottman, M.; Gaillard, J. L.; Herrmann, J. L., Acute respiratory failure involving an R variant of Mycobacterium abscessus. J Clin Microbiol 2009, 47 (1), 271-4. DOI: https://doi.org/10.1128/JCM.01478-08.

26. Jönsson, B. E.; Gilljam, M.; Lindblad, A.; Ridell, M.; Wold, A. E.; Welinder-Olsson, C., Molecular epidemiology of Mycobacterium abscessus, with focus on cystic fibrosis. J Clin Microbiol 2007, 45 (5), 1497-504. DOI: https://doi.org/10.1128/JCM.02592-06.

27. Luthra, S.; Rominski, A.; Sander, P., The Role of Antibiotic-Target-Modifying and Antibiotic-Modifying Enzymes in Mycobacterium abscessus Drug Resistance. Front Microbiol. 2018, 9, 2179. DOI: https://doi.org/10.3389/fmicb.2018.02179.

28. Nessar, R.; Cambau, E.; Reyrat, J. M.; Murray, A.; Gicquel, B., Mycobacterium abscessus: a new antibiotic nightmare. $J$ Antimicrob Chemother. 2012, 67 (4), 810-818. DOI: https://doi.org/10.1093/jac/dkr578.

29. Ripoll, F.; Pasek, S.; Schenowitz, C.; Dossat, C.; Barbe, V.; Rottman, M.; Macheras, E.; Heym, B.; Herrmann, J. L.; Daffe, M.; Brosch, R.; Risler, J. L.; Gaillard, J. L., Non mycobacterial 
virulence genes in the genome of the emerging pathogen Mycobacterium abscessus. PLoS ONE 2009, 4 (6), e5660. DOI: https://doi.org/10.1371/journal.pone.0005660.

30. Richard, M.; Gutiérrez, A. V.; Viljoen, A. J.; Ghigo, E.; Blaise, M.; Kremer, L., Mechanistic and Structural Insights Into the Unique TetR-Dependent Regulation of a Drug Efflux Pump in Mycobacterium abscessus. Front. Microbiol. 2018, 9, 649. DOI: https://doi.org/10.3389/fmicb.2018.00649.

31. Richard, M.; Gutiérrez, A. V.; Viljoen, A.; Rodriguez-Rincon, D.; Roquet-Baneres, F.; Blaise, M.; Everall, I.; Parkhill, J.; Floto, R. A.; Kremer, L., Mutations in the MAB_2299c TetR Regulator Confer Cross-Resistance to Clofazimine and Bedaquiline in Mycobacterium abscessus. Antimicrob Agents Chemother 2019, 63 (1), e01316-18. DOI: https://doi.org/10.1128/aac.01316-18.

32. Rominski, A.; Roditscheff, A.; Selchow, P.; Böttger, E. C.; Sander, P., Intrinsic rifamycin resistance of Mycobacterium abscessus is mediated by ADP-ribosyltransferase MAB_0591. $J$ Antimicrob Chemother. 2017, 72 (2), 376-384. DOI: https://doi.org/10.1093/jac/dkw466.

33. Schulze, C. J.; Navarro, G.; Ebert, D.; DeRisi, J.; Linington, R. G., Salinipostins A-K, LongChain Bicyclic Phosphotriesters as a Potent and Selective Antimalarial Chemotype. J. Org. Chem. 2015, 80, 1312-1320. DOI: https://doi.org/10.1021/jo5024409.

34. Zhao, M.; Wei, X.; Liu, X.; Dong, X.; Yu, R.; Wan, S.; Jiang, T., Total Synthesis of Marine Cyclic Enol-Phosphotriester Salinipostin Compounds. J. Ocean Univ. China 2018, 17 (3), 683-689. DOI: https://doi.org/10.1007/s11802-018-3540-8.

35. Oikawa, Y.; Sugano, K.; Yonemitsu, O., Meldrum's acid in organic synthesis. 2. A general and versatile synthesis of .beta.-keto esters. J Org Chem. 1978, 43 (10), 2087-2088. DOI: https://doi.org/10.1021/jo00404a066.

36. Mulholland, N. P.; Pattenden, G.; Walters, I. A. S., A concise and straightforward total synthesis of (+/-)-salinosporamide A, based on a biosynthesis model. Org Biomol Chem. 2008, 6 (15), 2782-2789. DOI: https://doi.org/10.1039/b803818j. 
37. Martin, B. P.; Vasilieva, E.; Dupureur, C. M.; Spilling, C. D., Synthesis and comparison of the biological activity of monocyclic phosphonate, difluorophosphonate and phosphate analogs of the natural AChE inhibitor cyclophostin. Bioorg Med Chem. 2015, 23, 7529-7534. DOI: http://dx.doi.org/10.1016/j.bmc.2015.10.044.

38. Herb, C.; Bayer, A.; Maier, M. E., Total Synthesis of Salicylihalamides A and B. Chem Eur J. 2004, 10 (22), 5649-5660. DOI: https://doi.org/10.1002/chem.200400617.

39. Pawlik, A.; Garnier, G.; Orgeur, M.; Tong, P.; Lohan, A.; Le Chevalier, F.; Sapriel, G.; Roux, A. L.; Conlon, K.; Honore, N.; Dillies, M. A.; Ma, L.; Bouchier, C.; Coppee, J. Y.; Gaillard, J. L.; Gordon, S. V.; Loftus, B.; Brosch, R.; Herrmann, J. L., Identification and characterization of the genetic changes responsible for the characteristic smooth-to-rough morphotype alterations of clinically persistent Mycobacterium abscessus. Mol Microbiol. 2013, 90 (3), 612-29. DOI: https://doi.org/10.1111/mmi.12387.

40. Medjahed, H.; Reyrat, J.-M., Construction of Mycobacterium abscessus Defined Glycopeptidolipid Mutants: Comparison of Genetic Tools. Appl Environ Microbiol. 2009, 75 (5), 1331-1338. DOI: https://doi.org/10.1128/aem.01914-08.

41. Roux, A. L.; Ray, A.; Pawlik, A.; Medjahed, H.; Etienne, G.; Rottman, M.; Catherinot, E.; Coppee, J. Y.; Chaoui, K.; Monsarrat, B.; Toubert, A.; Daffe, M.; Puzo, G.; Gaillard, J. L.; Brosch, R.; Dulphy, N.; Nigou, J.; Herrmann, J. L., Overexpression of proinflammatory TLR-2-signalling lipoproteins in hypervirulent mycobacterial variants. Cell Microbiol 2011, 13 (5), 692-704. DOI: https://doi.org/10.1111/j.1462-5822.2010.01565.x.

42. Bernut, A.; Herrmann, J. L.; Kissa, K.; Dubremetz, J. F.; Gaillard, J. L.; Lutfalla, G.; Kremer, L., Mycobacterium abscessus cording prevents phagocytosis and promotes abscess formation. Proc Natl Acad Sci USA 2014, 111 (10), E943-52. DOI: https://doi.org/10.1073/pnas.1321390111.

43. Ripoll, F.; Deshayes, C.; Pasek, S.; Laval, F.; Beretti, J.-L.; Biet, F.; Risler, J.-L.; Daffé, M.; Etienne, G.; Gaillard, J.-L.; Reyrat, J.-M., Genomics of glycopeptidolipid biosynthesis in 
Mycobacterium abscessus and M. chelonae. BMC Genomics 2007, 8 (1), 114. DOI: https://doi.org/10.1186/1471-2164-8-114.

44. Santucci, P.; Point, V.; Poncin, I.; Guy, A.; Crauste, C.; Serveau-Avesque, C.; Spilling, C. D.; Cavalier, J.-F.; Canaan, S., LipG a bifunctional phospholipase/thioesterase involved in mycobacterial envelope remodeling. Biosci Rep 2018, 38 (6), BSR20181953. DOI: https://doi.org/10.1042/BSR20181953.

45. Khoo, K. H.; Jarboe, E.; Barker, A.; Torrelles, J.; Kuo, C. W.; Chatterjee, D., Altered expression profile of the surface glycopeptidolipids in drug-resistant clinical isolates of Mycobacterium avium complex. J Biol Chem 1999, 274 (14), 9778-85. DOI: https://doi.org/10.1074/jbc.274.14.9778.

46. Sarathy, J. P.; Dartois, V.; Lee, E. J., The role of transport mechanisms in mycobacterium tuberculosis drug resistance and tolerance. Pharmaceuticals (Basel) 2012, 5 (11), 1210-35. DOI: https://doi.org/10.3390/ph5111210.

47. Dutta, S.; Malla, R. K.; Bandyopadhyay, S.; Spilling, C. D.; Dupureur, C. M., Synthesis and kinetic analysis of some phosphonate analogs of cyclophostin as inhibitors of human acetylcholinesterase. Bioorg. Med. Chem. 2010, 18 (6), 2265-74. DOI: https://doi.org/10.1016/j.bmc.2010.01.063.

48. Point, V.; Malla, R. K.; Carriere, F.; Canaan, S.; Spilling, C. D.; Cavalier, J. F., Enantioselective inhibition of microbial lipolytic enzymes by nonracemic monocyclic enolphosphonate analogues of cyclophostin. J Med Chem 2013, 56 (11), 4393-4401. DOI: https://doi.org/10.1021/jm4000787.

49. Tallman, K. R.; Levine, S. R.; Beatty, K. E., Small Molecule Probes Reveal Esterases with Persistent Activity in Dormant and Reactivating Mycobacterium tuberculosis. ACS Infect. Dis. 2016, 2 (12), 936-944. DOI: https://doi.org/10.1021/acsinfecdis.6b00135.

50. Lehmann, J.; Cheng, T. Y.; Aggarwal, A.; Park, A. S.; Zeiler, E.; Raju, R. M.; Akopian, T.; Kandror, O.; Sacchettini, J. C.; Moody, D. B.; Rubin, E. J.; Sieber, S. A., An Antibacterial beta- 
Lactone Kills Mycobacterium tuberculosis by Disrupting Mycolic Acid Biosynthesis. Angew Chem Int Ed Engl. 2018, 57 (1), 348-353. DOI: https://doi.org/10.1002/anie.201709365.

51. Koonin, E. V., Orthologs, Paralogs, and Evolutionary Genomics. Annu Rev Genet. 2005, 39 (1), 309-338. DOI: https://doi.org/10.1146/annurev.genet.39.073003.114725.

52. Griffin, J. E.; Gawronski, J. D.; DeJesus, M. A.; Ioerger, T. R.; Akerley, B. J.; Sassetti, C. M., High-Resolution Phenotypic Profiling Defines Genes Essential for Mycobacterial Growth and Cholesterol Catabolism. PLOS Pathog. 2011, 7 (9), e1002251. DOI: https://doi.org/10.1371/journal.ppat.1002251.

53. Sassetti, C. M.; Boyd, D. H.; Rubin, E. J., Genes required for mycobacterial growth defined by high density mutagenesis. Mol Microbiol 2003, 48 (1), 77-84. DOI: https://doi.org/10.1046/j.13652958.2003.03425.x.

54. Nasir, N.; Anant, A.; Vyas, R.; Biswal, B. K., Crystal structures of Mycobacterium tuberculosis HspAT and ArAT reveal structural basis of their distinct substrate specificities. Scientific Reports 2016, 6, 18880. DOI: https://doi.org/10.1038/srep18880.

55. Nguyen, P. C.; Delorme, V.; Bénarouche, A.; Guy, A.; Landry, V.; Audebert, S.; Pophillat, M.; Camoin, L.; Crauste, C.; Galano, J.-M.; Durand, T.; Brodin, P.; Canaan, S.; Cavalier, J.-F., Oxadiazolone derivatives, new promising multi-target inhibitors against M. tuberculosis. Bioorg Chem. 2018, 81, 414-424. DOI: https://doi.org/10.1016/j.bioorg.2018.08.025.

56. Sacchettini, J. C.; Ronning, D. R., The mycobacterial antigens 85 complex--from structure to function: response. Trends in Microbiology 2000, 8 (10), 441. DOI: https://doi.org/10.1016/S0966842X(00)01843-6.

57. Backus, K. M.; Dolan, M. A.; Barry, C. S.; Joe, M.; McPhie, P.; Boshoff, H. I. M.; Lowary, T. L.; Davis, B. G.; Barry, C. E., The Three Mycobacterium tuberculosis Antigen 85 Isoforms Have Unique Substrates and Activities Determined by Non-active Site Regions. J. Biol. Chem. 2014, 289 (36), 25041-25053. DOI: https://doi.org/10.1074/jbc.M114.581579. 
58. Cai, L.; Zhao, X.; Jiang, T.; Qiu, J.; Owusu, L.; Ma, Y.; Wang, B.; Xin, Y., Prokaryotic Expression, Identification and Bioinformatics Analysis of the Mycobacterium tuberculosis Rv3807c Gene Encoding the Putative Enzyme Committed to Decaprenylphosphoryl-d-arabinose Synthesis. Indian journal of microbiology 2014, 54 (1), 46-51. DOI: https://doi.org/10.1007/s12088-013-04188.

59. Mills, J. A.; Motichka, K.; Jucker, M.; Wu, H. P.; Uhlik, B. C.; Stern, R. J.; Scherman, M. S.; Vissa, V. D.; Pan, F.; Kundu, M.; Ma, Y. F.; McNeil, M., Inactivation of the mycobacterial rhamnosyltransferase, which is needed for the formation of the arabinogalactan-peptidoglycan linker, leads to irreversible loss of viability. J Biol Chem. 2004, 279 (42), 43540-6. DOI: https://doi.org/10.1074/jbc.M407782200.

60. Ferraris, D. M.; Spallek, R.; Oehlmann, W.; Singh, M.; Rizzi, M., Structures of citrate synthase and malate dehydrogenase of Mycobacterium tuberculosis. Proteins 2015, 83 (2), 389-94. DOI: https://doi.org/10.1002/prot.24743.

61. O'Brien, J.; Wilson, I.; Orton, T.; Pognan, F., Investigation of the Alamar Blue (resazurin) fluorescent dye for the assessment of mammalian cell cytotoxicity. Eur J Biochem. 2000, 267 (17), 5421-5426. DOI: https://doi.org/10.1046/j.1432-1327.2000.01606.x.

62. Christophe, T.; Jackson, M.; Jeon, H. K.; Fenistein, D.; Contreras-Dominguez, M.; Kim, J.; Genovesio, A.; Carralot, J. P.; Ewann, F.; Kim, E. H.; Lee, S. Y.; Kang, S.; Seo, M. J.; Park, E. J.; Skovierova, H.; Pham, H.; Riccardi, G.; Nam, J. Y.; Marsollier, L.; Kempf, M.; Joly-Guillou, M. L.; Oh, T.; Shin, W. K.; No, Z.; Nehrbass, U.; Brosch, R.; Cole, S. T.; Brodin, P., High content screening identifies decaprenyl-phosphoribose 2 ' epimerase as a target for intracellular antimycobacterial $\begin{array}{llllll}\text { inhibitors. } & P L o S & \text { pathogens } & \text { 2009, } & 5 & \text { (10), }\end{array}$ https://doi.org/10.1371/journal.ppat.1000645.

63. Rodrigues Felix, C.; Gupta, R.; Geden, S.; Roberts, J.; Winder, P.; Pomponi, S. A.; Diaz, M. C.; Reed, J. K.; Wright, A. E.; Rohde, K. H., Selective Killing of Dormant Mycobacterium 
tuberculosis by Marine Natural Products. Antimicrob Agents Chemother 2017, 61 (8), e00743-17. DOI: https://doi.org/10.1128/aac.00743-17.

64. Strober, W., Trypan Blue Exclusion Test of Cell Viability. Current Protocols in Immunology 1997, 21 (1), A.3B.1-A.3B.2. DOI: https://doi.org/10.1002/0471142735.ima03bs21.

65. Sambandamurthy, V. K.; Derrick, S. C.; Hsu, T.; Chen, B.; Larsen, M. H.; Jalapathy, K. V.; Chen, M.; Kim, J.; Porcelli, S. A.; Chan, J.; Morris, S. L.; Jacobs, W. R., Jr., Mycobacterium tuberculosis DeltaRD1 DeltapanCD: a safe and limited replicating mutant strain that protects immunocompetent and immunocompromised mice against experimental tuberculosis. Vaccine 2006, 24 (37-39), 6309-6320. DOI: https://doi.org/10.1016/j.vaccine.2006.05.097.

66. Blanco-Ruano, D.; Roberts, D. M.; Gonzalez-Del-Rio, R.; Álvarez, D.; Rebollo, M. J.; PérezHerrán, E.; Mendoza, A., Antimicrobial Susceptibility Testing for Mycobacterium sp. In Mycobacteria Protocols, Parish, T.; Roberts, M. D., Eds. Springer New York: New York, NY, 2015; pp 257-268. DOI: https://doi.org/10.1007/978-1-4939-2450-9_15.

67. Shevchenko, A.; Wilm, M.; Vorm, O.; Mann, M., Mass spectrometric sequencing of proteins silver-stained polyacrylamide gels. Anal Chem. 1996, 68 (5), 850-858. DOI: https://doi.org/10.1021/ac950914h.

68. Cox, J.; Mann, M., MaxQuant enables high peptide identification rates, individualized p.p.b.range mass accuracies and proteome-wide protein quantification. Nat Biotechnol. 2008, 26 (12), 1367-1372. DOI: https://doi.org/10.1038/nbt.1511.

69. Vizcaino, J. A.; Deutsch, E. W.; Wang, R.; Csordas, A.; Reisinger, F.; Rios, D.; Dianes, J. A.; Sun, Z.; Farrah, T.; Bandeira, N.; Binz, P. A.; Xenarios, I.; Eisenacher, M.; Mayer, G.; Gatto, L.; Campos, A.; Chalkley, R. J.; Kraus, H. J.; Albar, J. P.; Martinez-Bartolome, S.; Apweiler, R.; Omenn, G. S.; Martens, L.; Jones, A. R.; Hermjakob, H., ProteomeXchange provides globally coordinated proteomics data submission and dissemination. Nat Biotechnol. 2014, 32 (3), 223-226. DOI: https://doi.org/10.1038/nbt.2839. 


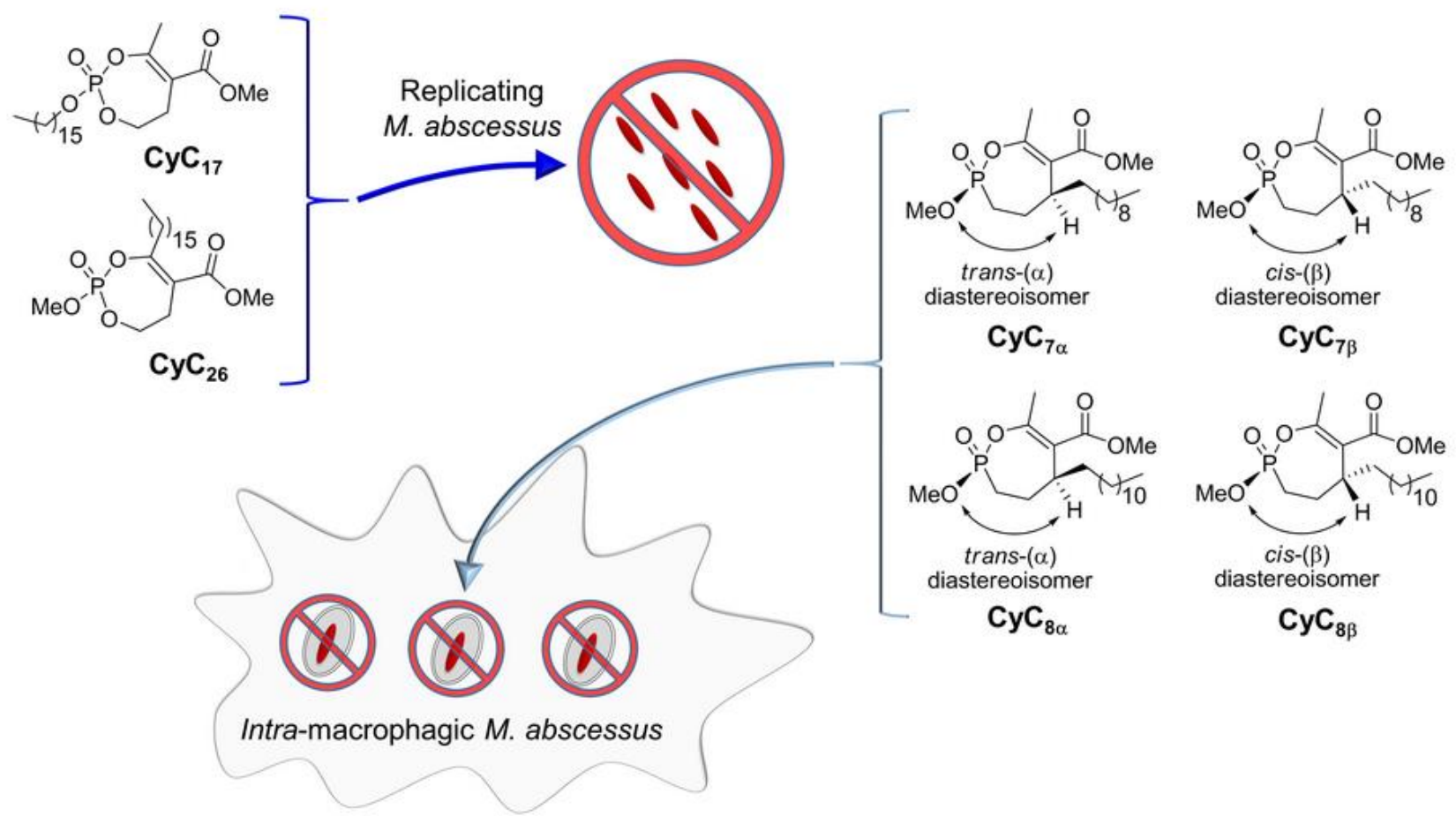

